Article

\title{
Bibliometric Maps of BIM and BIM in Universities: A Comparative Analysis
}

\author{
Mehdi Chihib ${ }^{1}$, Esther Salmerón-Manzano ${ }^{2}$, Nuria Novas ${ }^{1}[$ and \\ Francisco Manzano-Agugliaro ${ }^{1, * \mathbb{D}}$ \\ 1 Department of Engineering, CEIA3, University of Almeria, 04120 Almeria, Spain \\ 2 Faculty of Law, Universidad Internacional de La Rioja (UNIR), Av. de la Paz, 137, 26006 Logroño, Spain \\ * Correspondence: fmanzano@ual.es
}

Received: 27 May 2019; Accepted: 9 August 2019; Published: 14 August 2019

check for updates

\begin{abstract}
Building Information Modeling (BIM) is increasingly important in the architecture and engineering fields, and especially in the field of sustainability through the study of energy. This study performs a bibliometric study analysis of BIM publications based on the Scopus database during the whole period from 2003 to 2018 . The aim was to establish a comparison of bibliometric maps of the building information model and BIM in universities. The analyzed data included 4307 records produced by a total of 10,636 distinct authors from 314 institutions. Engineering and computer science were found to be the main scientific fields involved in BIM research. Architectural design are the central theme keywords, followed by information theory and construction industry. The final stage of the study focuses on the detection of clusters in which global research in this field is grouped. The main clusters found were those related to the BIM cycle, including construction management, documentation and analysis, architecture and design, construction/fabrication, and operation and maintenance (related to energy or sustainability). However, the clusters of the last phases such as demolition and renovation are not present, which indicates that this field suntil needs to be further developed and researched. With regard to the evolution of research, it has been observed how information technologies have been integrated over the entire spectrum of internet of things (IoT). A final key factor in the implementation of the BIM is its inclusion in the curriculum of technical careers related to areas of construction such as civil engineering or architecture.
\end{abstract}

Keywords: building information modeling (BIM); legal aspects; bibliometric; sustainability; clustering

\section{Introduction}

The growing requirements for establishing sophisticated buildings are making AEC (Architecture Engineering and Construction) projects more complex, while technological advances are helping the participants to collaborate more effectively during the construction process. In fact, the building information model (BIM) provides an intelligent model-based process that connects AEC professionals and helps them to design, build, and operate building infrastructure [1]. This tool allows professionals to design 3D models that incorporate data associated with physical and operational properties, which will help architects, engineers, and contractors to work on a coordinated digital model, giving everyone a better insight into how their work fits in the overall project [2]. BIM systems encourage greater cooperation between stakeholders through a unique integrated model during the design and construction stages. Adopting BIM in the construction industry will lead eventually to a better planning and preparation process by detecting conflicts between elements and improving coordination. In addition, it will help reduce time costing errors and help decision makers to increase their efficiency during the construction phase, and finally will help facilities management with future changes and renovation work. 
BIM is the result of an international collaborative progress starting from Japan and moving to Europe and all the way to Northern America, so the history of this concept is not attributed to one name or one place alone. Although the BIM concept has existed since the 1970s, its development went through many steps until this term was first used officially to identify this notion [3]. The first commercial software known as computer-aided manufacturing (CAM) was developed by Dr. Patrick J. Hanratty in 1957. This numerical control machining technology has progressed to become computer-aided manufacturing [4]. Then, he immersed himself in computer-generated graphics and in 1961 developed DAC (Design Automated by Computer), which became later the first system that used CAM/CAD (Computer-Aided Manufacturing / Computer-Aided Design) interactive graphics [5]. The Augmenting Human Intellect paper where the BIM foundation was first documented was published by Douglas C. Englebart in 1962. With the incorporation of object-based systems, this BIM tool allowed architects to introduce several features and specifications for a building. This new advance made the fusion of parametric manipulation and a relational database possible and as a result the $2 \mathrm{D}$ illustration of the current design was formed [6]. Afterwards, 3D representations were developed with the Building Description System (BDS) illustrated by Charles Eastman et al. (1975). In their publication, they describe a generic prototype of BDS and consider the perspectives of parametric design and 3D representations with a "single integrated database for visual and quantitative analysis" [7].

After two years, the requirement to integrate building elements and monitor data accuracy was considered, in order to be used as a tool for estimating structural design costs. The Graphic Language for Interactive Design (GLIDE) tool was developed to implement this utility that allows for more reliable and accurate designs. However, both BDS and GLIDE have limited themselves to including only the design stage of the project, which would not allow the immersion of the different stages of the project life cycle [8]. By the year 1984, personal computers began building modeling programs, which included the first BIM (2D CAD) software used worldwide. However, this software wasn't operational until 1986, when Robert Aish used it in large and complex projects such as the renovation of the Heathrow airport terminal [9]. In the 1990s, several companies began to develop BIM tools, such as the Lawrence Berkeley National Laboratory [10]. Autodesk also began using the BIM concept in 2002 when it purchased the Texan company Revit Technology Corporation [11]. The Graphisoft company created the teamwork concept so that team members would be able to easily share BIM data with each other [12].

The complication of buildings and structures, increased construction and the imperative need to reduce design time, the increase in international design cooperation, and other factors led to the accelerated development of computer design tools.

By the early 2000s, objects and shapes have fully incorporated different type of data in the same file, meaning the designer, contractors, engineers and the owner could all work collaboratively on one centralized collaborative model. Objects and shapes had completely incorporated different types of data into the same file, allowing the designer, contractors, engineers, and owner to work collaboratively on a centralized collaboration model. BIM platforms such as the one shown in reference [13] have been created to incorporate parametric flexibility and sculpture geometry that supports NURBS (non-uniform rational B-spline) surfaces, and provides software that larger teams of architects and engineers can use to collaborate on an integrated model based on using a coherent system rather than a set of separate drawings. The new software works with all the information concerning the construction project, while the 3D model can include architectural, structural, electrical, sanitary, plumbing, Heating, Ventilating and Air Conditioning (HVAC) installation, and fire alarm system designs. All of these layers are merged into a BIM file that can be accessed by project holders at any time and from any location [13,14]. Advanced parametric techniques are then introduced into the BIM software [15], which can process complex and contemporary architectural shapes, enabling designers to create curved and complex architectural shapes. With the advancement of computational design technologies, more unique building designs will be realized [16-21].

BIM 4D modeling is employed in combination with the Geographic information system (GIS) to create a safe execution sequence of the process in order to enhance the visual tracking of construction 
supply chain management [22-24]. This can only prove that the BIM platform has a great potential to integrate various innovative operations related to construction. However, to improve the monitoring of the construction process $[25,26]$, companies are using remote sensing technology to develop an approach called defect management for automatic quality inspection.

In the last decade, BIM technologies have improved greatly with the help of information modeling, meaning it is now possible to solve problems that were unimaginable years ago [27]. These technologies have introduced designer supervision, construction cost planning, risk management, etc. State-of-the-art architecture with unique structures and hazardous facilities, whose projects are subject to mandatory government expertise, can be addressed without great difficulty with the help of these powerful tools [28].

Northern European countries such as Finland adopted BIM regulations, e.g., Common BIM Requirement 2012 (COBIM). In 2016, the U.K became in the first country to legally mandat the use of BIM [29] for public funded projects. Germany is mandating BIM for all transportation projects so teams can collaborate and work in the same model $[17,19]$, which will be useful in so many ways such as dealing with predictive risks and maintenance, improving $g$ timelines and cost savings, as well as asset tracking and facilities management. Government agencies are using BIM software to plan and operate diverse forms of physical infrastructure, such as public sanitation, communication utilities, electricity grids, roads, bridges, and ports [3]. Several European and Asian countries, as well as Australia, and the USA have demanded the use of BIM in projects or have published formal standards of good practice [30]. A study at the Northumbria University campus used BIM to improve the collection of data and its accessibility for facilities management [31]. The digital representation of public infrastructure will not only help authorities to manage its current artworks but also will help them to plan better for future projects to avoid interference and unpredicted modifications.

A BIM execution plan for project implementation would help to explain the details of the necessary checklist and standards [32], such as ISO/TC 59/SC 13. These standards form the foundation for accurate and efficient communication and commerce that are required by the off-site construction industry [33]. Regrettably, this is not usually part of the contract. As such, that Northumbria University campus study had revealed insightful implications into significant legal aspects or contract provisions that need to be included in BIM contracts [34]. As an example, in the literature, it is possible to find engineering, procurement, and construction (EPC) contracting, which enables a contractor to be responsible for all works associated with the design, procurement, erection, and testing of a facility [35]. It is possible to find hydro-supported structures [36] being used as offshore wind turbines [37]. Some authors even propose the application of blockchain or smart contract [38] technologies as a possibility for this type of contract $[39,40]$.

With the growing awareness of society and its contribution to maintaining sustainable systems, the construction industry has taken on this social concern and buildings are now designed with energy efficiency in mind. For this purpose, BEM has been combined with BIM. With this combination, the construction industry has the tools needed to solve problems related to the integrated energy analysis of buildings [41,42]. Another objective is the promotion for the construction of green buildings, the practice of building in a way that safeguards the natural environment [43].

Environmental sustainability concerns are frequently addressed as a complement to building design by pursuing ad hoc approaches to project implementation [44]. As a consequence, the most common problem in reaching a sustainable construction result is the lack of the right information at the right time to make crucial judgments. Furthermore, the design of these high performing buildings is a non-linear, complex, iterative, and multi-disciplinary process that requires efficient collaboration between interdisciplinary teams from the first stages to achieve sustainable outcomes [45]. Construction practitioners make extensive use of performance analysis tools to predict and quantify sustainability issues from the earliest stages of design and significantly improve quality and cost over the life cycle of a building [45]. There are very extensive and recent review studies on BIM and sustainability [46], noting that little work has been conducted about how it could be applied in refurbishment and demolition; but highlighting that BIM can improve social sustainability in two main areas: BIM provides a better facility design for a society's high standard of living. BIM transforms conventional practice, which is 
often highly fragmented, into a better collaborative effort that strengthens the working relationships among project participants. And this review [46] concludes that future policies of BIM for sustainability should consider improving the interoperability issue among BIM software and energy-simulation tools.

From an engineering point of view, it is important to reflect the complexity of new ways of working. This mixed set of knowledge, skills, and attitudes is essential to strengthen productivity, entrepreneurship, and the pursuit of excellent performance in an environment increasingly based on technologically advanced and sustainable outcomes [47]. A clear example of this involves developing effective measures using a "project-based learning" technique to improve student learning outcomes for the implementation of BIM in the area of sustainability [48]. Therefore, innovative concepts such as sustainability, green concepts, planning processes, or project execution are key aspects to evaluate the key benefits of BIM, and these concepts should be integrated in order to advance their curricula [49].

In this study, there are two objectives. to the first is analyze the background of the whole work published in relation to the BIM subject as bibliometric maps of this subject, and to see which clusters this scientific field is grouped around. And the second objective, given the importance it has for sustainability, is to determine which works of BIM are used in universities to contribute to their sustainability.

The previous published studies of bibliometric analysis on BIM focus on very specific aspects. For example, a study by Badrinath et al. (2016) [33] focuses on how the BIM is taught and then used for communication and visualization. That study was based on the bibliometric analysis of 445 BIM articles, but above all it was based on double keywords not covering the whole subject, these keywords were: "academic BIM education", "BIM curriculum", and "BIM course". Although the work is interesting, it is focused on a very specific area, which is academic BIM education. It was concluded that the case studies and experiences were the dominant type of publication.

In the literature there are other works focused on bibliometric studies of the BIM, but all of them make a subjective classification, and are based on databases other than those used of this study, for example in the WoS ${ }^{\mathrm{TM}}$ Core Collection [50] or Web of Science [51]. And although some of them open an important temporal window, from 1990 to 2016 only 567 publications appeared, and the ones which analyzed the relevant topic only numbered 445 [52].

Through Scopus, it is possible to find some bibliometric work but in a very short period of time (2006-2016) [53]. Although it uses community or cluster detection, it found only 4 clusters for 1031 available studies, it is notable that this work was looking for the specific topic of BIM-based Construction Networks (BbCNs). On the subject of the research, it was discovered that collaboration was a concept researched in isolation and without strong connections to other key areas of BIM research. Other works based on Scopus are state of the art revision works [54], and the database was therefore not used only to have a list of published works, but also to develop a bibliometric analysis. However, Scopus covers a wider range of journals in the area of construction project management than the WoS and contains more recent publications than other databases [55].

\section{Research Methodology}

The flowchart of the research methodology is shown in Figure 1. In this study, all the publications (4307) were collected from Elsevier Scopus database. This platform is useful for bibliometric studies because it allows you to download massive information for numerous bibliometric analysis. The search was conducted in March 2019 to extract research publications that include the following citations "BIM" or "BIM in University" and "Building Information Model" or "Building Information Model in University "in the title, abstract and/or keywords within the period (2003-2018). The following search queries were used: (TITLE-ABS-KEY (\{BIM\} OR \{Building Information Model\}), and another one specific for plant: (TITLE-ABS-KEY ( $\{$ BIM $\}$ OR \{Building Information Model $\}$ AND $\left\{\right.$ Universit $\left.\left.{ }^{*}\right\}\right)$. Thus, in the first query all the published works on BIM have been found, and the second query acts as a filter on the first, where only those works that deal with the subject of the university remain. It should be noted that the subject categories are the result of the Scopus indexation. 


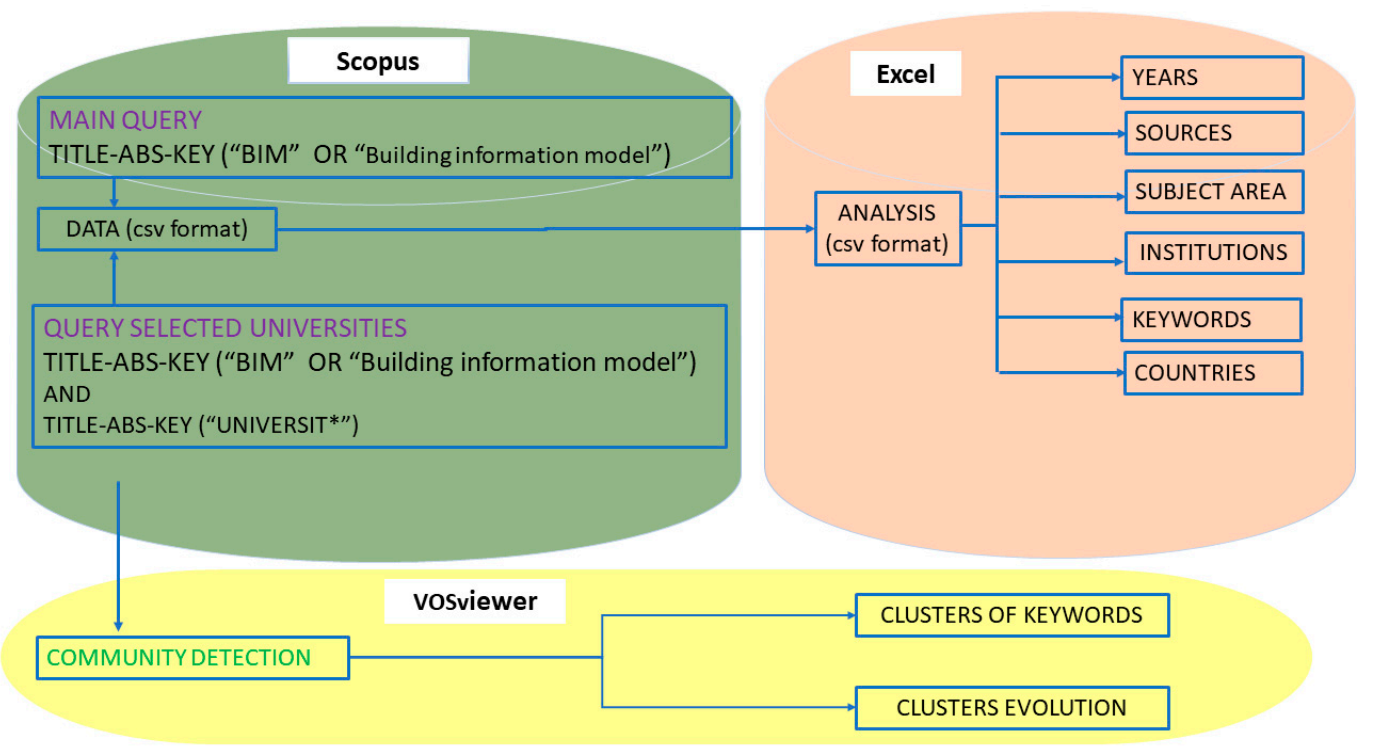

Figure 1. Flowchart of the information search and analysis.

\subsection{Data Collection}

The main query provides information such as the source of publications according to their authors, institutions, as well as their geographic locations. The publications acquired have been classified based on the following characteristics: the number of publications per year, distribution by subject area, document category, institution, and by country. The word frequency analysis is carried out to reflect the research field, and the core subject of BIM literature keywords are extracted and collected by filtering the main query. The records were consecutively processed using excel sheets, as well as the generation of the result corresponding graphics.

\subsection{Community Detection}

Community detection is a procedure that identifies geographic locations, trends, and other parameters of a large group of elements that interact with each other. This relationship between elements could vary in intensity that transcribes their dependency on each other. These multiple interdependent nodes evolve around one central core that is highly cohesive, while the density of interactivities decreases as we go far from the center. This structure is called a cluster, and the union of multiple clusters form from a complex network, which usually comes out in the form of a neural network. In this work we have proceeded by using Sw VOSviewer to detect the network community. This tool illustrates the most significant clusters based on the hierarchical connectivity algorithms [37]. This community detection software, VOSviewer, is free software available online that allows the direct import of data in the csv format exported from Scopus and also allows the figures to be exported to a large range of graphical formats. The VOSviewer delivers three displays: network visualization as clusters, overlay visualization as temporal evolution, and density visualization. In all of these cases, the parameters chosen for the analysis were: normalization method (association strength), layout (attraction 2, repulsion 0), clustering (resolution 1.00, minimum cluster size 1), and rotate (90 degrees).

\section{Results and Discussion}

\subsection{Evolution of the Number of Publication Over the Years}

We can observe in Figure 2 that the evolution of BIM in university publications is relatively weak compared to BIM global, which has a parabolic pattern over the period studied. The figure also shows that scientific production started to increase substantially since 2007. The total number of BIM and BIM in university publications are 4307 and 274 , respectively (3.36\%). 


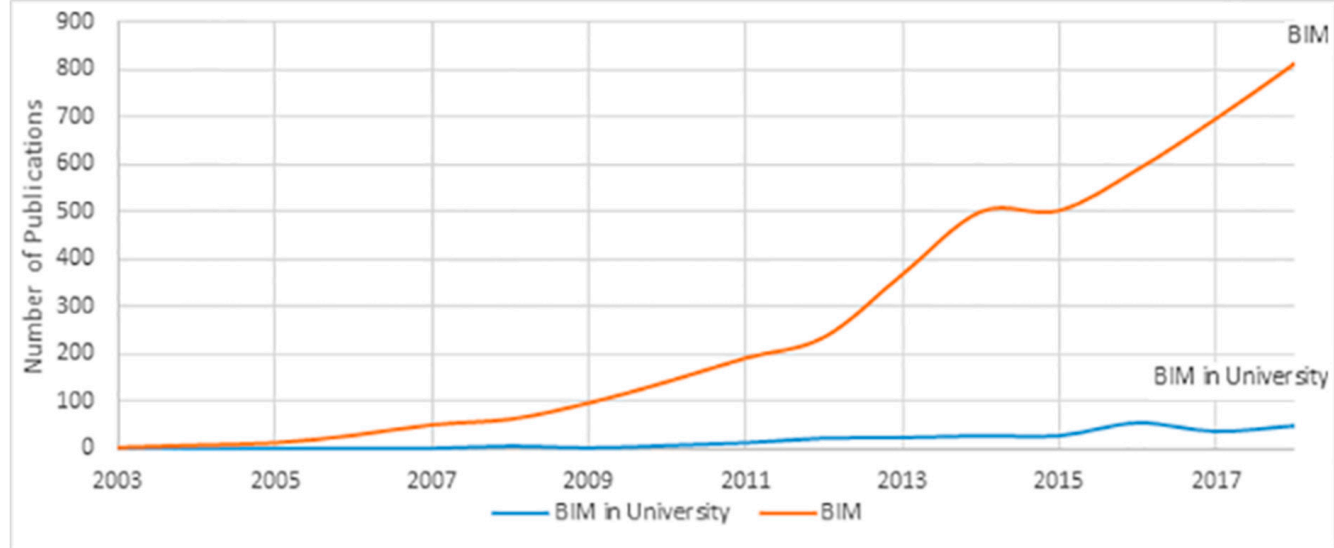

Figure 2. Evolution of the scientific production of BIM (2003-2018).

\subsection{Distribution of Output in Subject Categories}

Based on the Scopus classification, the distribution of publications on BIM research fields covered a total of 22 subject areas, see Figure 3. The largest number of documents corresponds to engineering (3234 records, $44 \%$ ), computer science (1423 records, 20\%), and business management and accounting (494 records, $7 \%$ ) while the fourth largest number is for social sciences (389 records, $5 \%$ ), the fifth is for mathematics ( 341 records, $5 \%$ ) and the sixth is for environmental sciences ( 250 records, $3 \%$ ). It is worth mentioning that a document can be related to more than one field of research at the same time. These six areas count for about $85 \%$ of all publications (Figure 3). The distribution of publications on BIM in the university research area reduced the number of subject areas, enclosing only 18 subject areas. The four first areas were the same as those showed by the global BIM research field. The first highest area according to number of publications was engineering ( 218 records, $43 \%$ ), computer science was the second highest area (68 records, 13\%), business management and accounting was the third highest (52 records, $10 \%$ ), and social science was the fourth highest (48 records, $10 \%$ ). Arts and humanities were in the fifth position (22 records, $4 \%$ ), while energy accounted for the sixth position (17 records, 3\%). BIM studies are mainly focusing on engineering and computer science, which involves architecture, mechanical structure design, and construction. It can be concluded that they are essentially the same categories that are given significance in both cases.
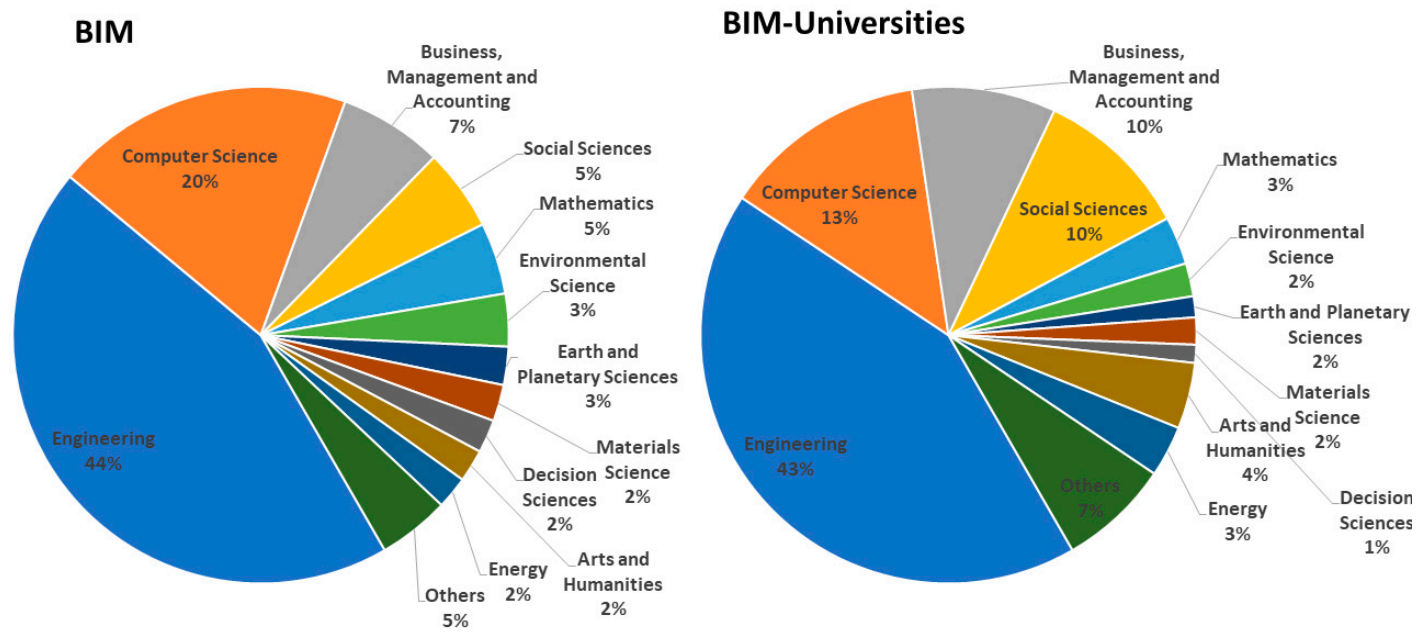

Figure 3. Distribution (\%) of worldwide research of BIM and BIM in universities by subject area. 


\subsection{Types of Publications}

The most common means used in scientific diffusion are journal articles. However, in the case of BIM, conference papers are the type of publication that counts for the biggest share with $49 \%$, followed by scientific articles with $41 \%$ and articles in review with $3 \%$, followed by books and book chapters with $3 \%$. Figure 4 shows the percentage of the types of scientific production distributed on the building information model theme.

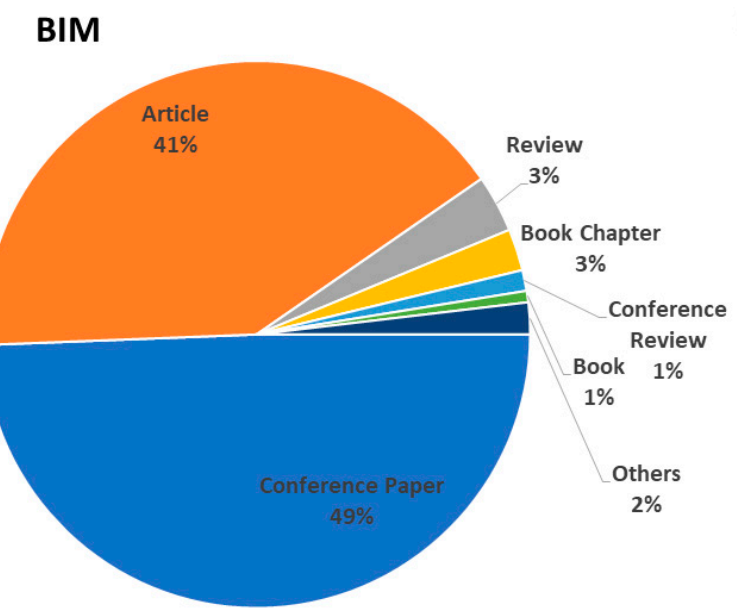

BIM-Universities

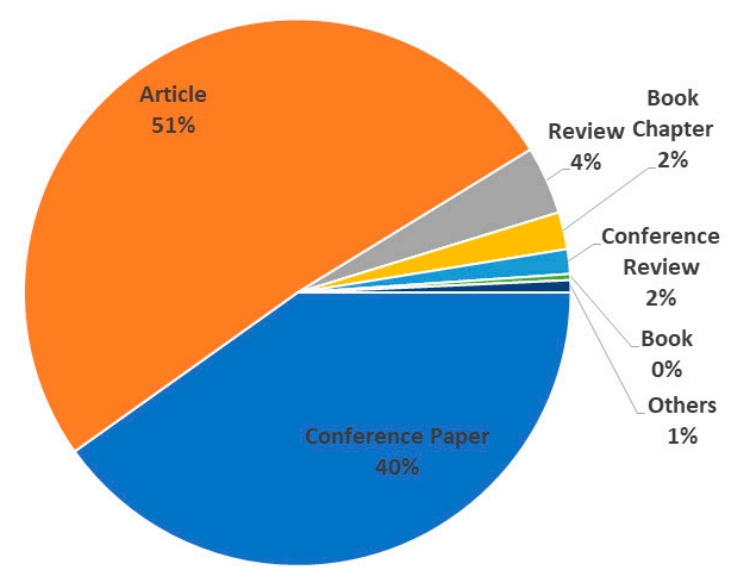

Figure 4. Distribution by publication type related respectively for global BIM and BIM in universities.

Regarding BIM in universities, scientific articles are the type of publication that counts for the largest share of BIM in university publications with $51 \%$, followed by conference papers with $40 \%$, articles in review with 3\%, while books and book chapters had $2 \%$. Figure 4 shows the percentages of the types of scientific production distributed on BIM in universities. It is remarkable that in the case of the universities the topic of BIM is predominant in the articles, while for BIM in general the topic is predominant in the conference papers. In general, the higher the percentage of conferences, the more novel the topic is. And when the percentage of books and book chapters is high, this indicates a topic that is scientifically established. BIM is therefore shown to be very novel, given the large percentage of conference paper in both cases.

\subsection{Distribution by Countries and Institutions}

If the distribution by country of the publications in BIM is represented (see Figure 5), it can be seen that the 10 highest countries are: the United States (20\%), the United Kingdom (10\%), China (9\%), Australia (6\%), South Korea (6\%), Germany (5\%), Canada (4\%), Malaysia (3\%), Italy (3\%), and Taiwan $(3 \%)$. It can be seen that almost $40 \%$ of publications are grouped in the first three countries.

BIM research has been produced in more than 160 institutions. Table 1 shows the top 20 the most productive institutions, with more than 4307 publications covering the BIM concept in the period studied. The first sixteen institutions (10\% of total institutions) are from the USA, Australia, the UK, South Korea, China, Italy, Malaysia, Israel, and Germany. They are represented by the following affiliations: the Georgia Institute of technology (USA), Curtin University (UK), University of Florida (USA), University of Salford (UK), Kyung Hee University (South Korea), Pennsylvania State (USA), Hong Kong Polytechnic University (China), Politecnico di Milano (Italy), University Tongji University (China), Hanyang University (South Korea), Universiti Teknologi Malaysia (Malaysia), Cardiff University (UK), University College London (UK), Tsinghua University (China), Israel Institute of Technology (Israel), and the Technical University of Munich (Germany). Universities from the USA have the most representations with 988 publications, UK has the second highest production with 518 records, while China has the third highest rank with 460 publications. BIM in university publications have been produced in the same number of institutions as the global BIM. 


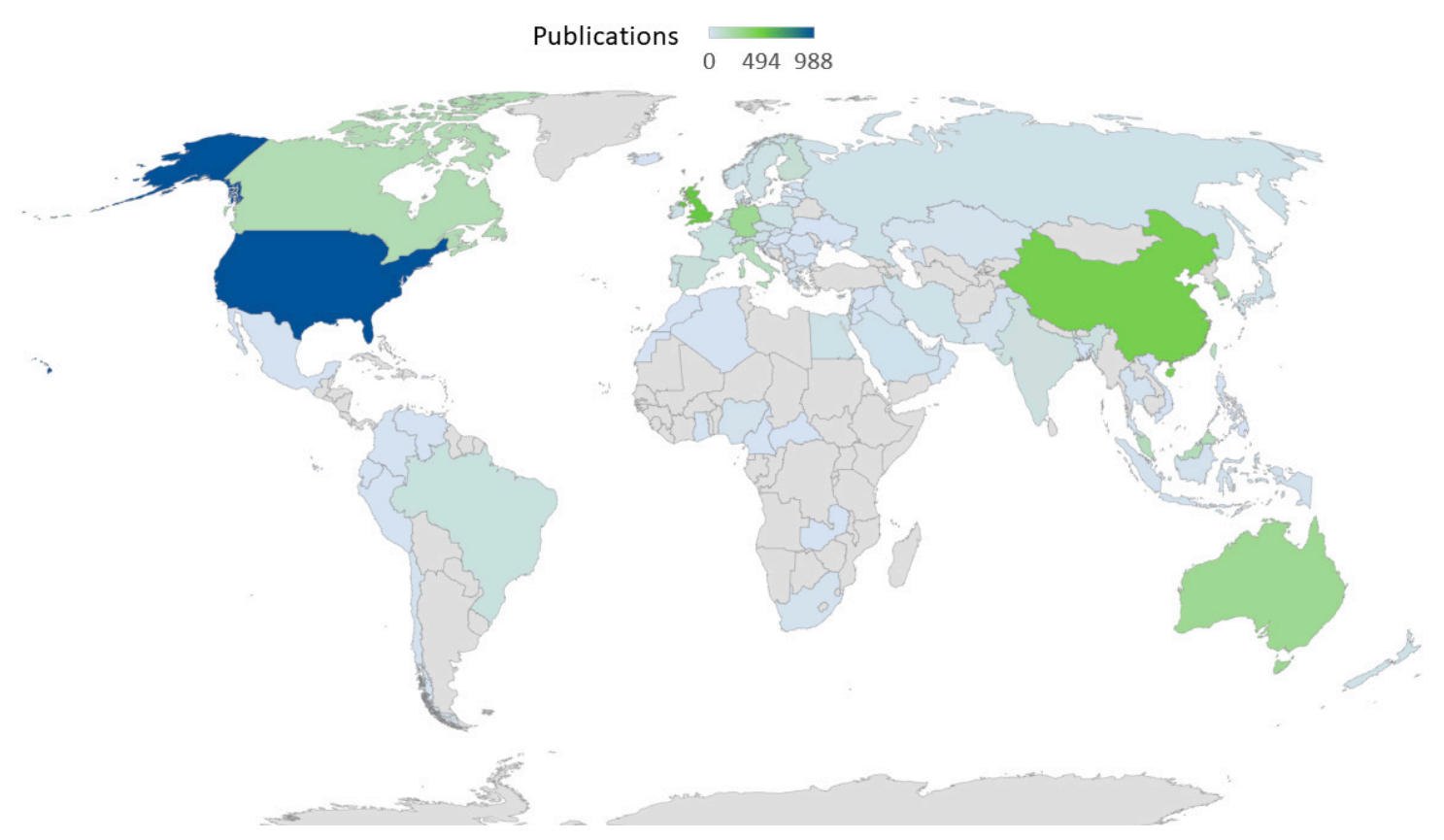

Figure 5. Distribution by countries of BIM publications.

Table 1. Classification of research institutions by record and countries.

\begin{tabular}{|c|c|c|c|c|c|}
\hline \multicolumn{3}{|l|}{ BIM } & \multicolumn{3}{|c|}{ BIM in University } \\
\hline Affiliation & Country & $\mathbf{N}$ & Affiliation & Country & $\mathbf{N}$ \\
\hline Georgia Institute of Technology & USA & 101 & Pennsylvania State University & USA & 9 \\
\hline Curtin University & UK & 98 & Hong Kong Polytechnic University & China & 9 \\
\hline University of Florida & USA & 93 & Tsinghua University & China & 8 \\
\hline University of Salford & UK & 68 & Arizona State University & USA & 6 \\
\hline Kyung Hee University & South Korea & 56 & Ceské vysoké ucení technické v Praze & $\begin{array}{l}\text { Czech The Czech } \\
\text { Republic }\end{array}$ & 5 \\
\hline Pennsylvania State University & USA & 55 & $\begin{array}{c}\text { National Taipei University of } \\
\text { Technology }\end{array}$ & China & 4 \\
\hline Hong Kong Polytechnic University & China & 54 & University of Southern California & USA & 4 \\
\hline Politecnico di Milano & Italy & 49 & $\begin{array}{l}\text { Vilniaus Gedimino technikos } \\
\text { universitetas }\end{array}$ & Lithuania & 4 \\
\hline Tongji University & China & 49 & Universidade de Lisboa & Portugal & 4 \\
\hline Hanyang University & South Korea & 48 & Helsingin Yliopisto & Sweden & 3 \\
\hline Universiti Teknologi Malaysia & Malaysia & 47 & University of Texas at San Antonio & USA & 3 \\
\hline Cardiff University & UK & 46 & National Taiwan University & Taiwan & 3 \\
\hline UCL (University College London) & UK & 43 & University of Salford & UK & 3 \\
\hline Tsinghua University & China & 43 & University of Wyoming & USA & 3 \\
\hline $\begin{array}{c}\text { Technion-Israel Institute of } \\
\text { Technology }\end{array}$ & Israel & 42 & Universitat d'Alacant & Spain & 3 \\
\hline Technical University of Munich & Germany & 41 & International University of Florida & USA & 3 \\
\hline
\end{tabular}

However, the BIM in university research area had more than 274 publications in the studied period, although this number remains small in comparison to BIM global. The sixteen most productive institutions (10\% of total institutions) have been developed in the following countries: the USA, the Czech Republic, the UK, China, Lithuania, Spain, Portugal, and Sweden, all of which are represented by the following universities: Pennsylvania State University (USA), Hong Kong Polytechnic University (China), Tsinghua University (China), Arizona State University (USA), Ceské vysoké Ucení technické v Praze (Czech Republic), National Taipei University of Technology (China), University of Southern California (USA), Vilniaus Gedimino technikos Universitetas (Lithuania), Universidade de Lisboa (Portugal), Helsingin Yliopisto (Sweden), University of Texas at San Antonio (U.S.A), National Taiwan University (Taiwan), University of Salford (UK), University of Wyoming (USA), Universitat d'Alacant (Spain), and the Florida International University (USA). Institutions from the USA are the most highly 
represented with 79 publications, the second country had 28 publications, while Chinese universities had the third rank with 18 publications.

\subsection{Relationships between Countries}

Figure 6 shows the labeled clusters with the relationships between the countries of the various publications. This is generally determined by the co-authorship of articles, i.e., authors from different countries who wrote the same article. Each element represents a country and the size of these elements is determined by the total number of publications of this country. The network counts 10 communities, their rank order respectively is the USA, the UK, China, Australia, Germany, South Korea, Italy, Spain, Finland, and Taiwan. It is observed that in the clusters of these countries, there is a major correlation with nearby or neighboring countries, which is not frequently found in scientific subjects. Examples of this include the USA with Canada, China with Hong Kong, Germany with Austria or Switzerland, the UK with Ireland, Finland with Norway, or the Czech Republic with Poland.

The countries that are in the middle of the cluster are the ones who are linked with the most nodes. Language plays a key role in the interconnections between countries. The largest community is the one that evolves around the USA. These publications are written mostly in English in more than $92 \%$ of cases, although the Chinese language has also appeared in 5.5\% of publications since 2006, while other languages numbered less than $1 \%$ and included Japanese, Dutch, German, Polish, Russian, Spanish, and French.

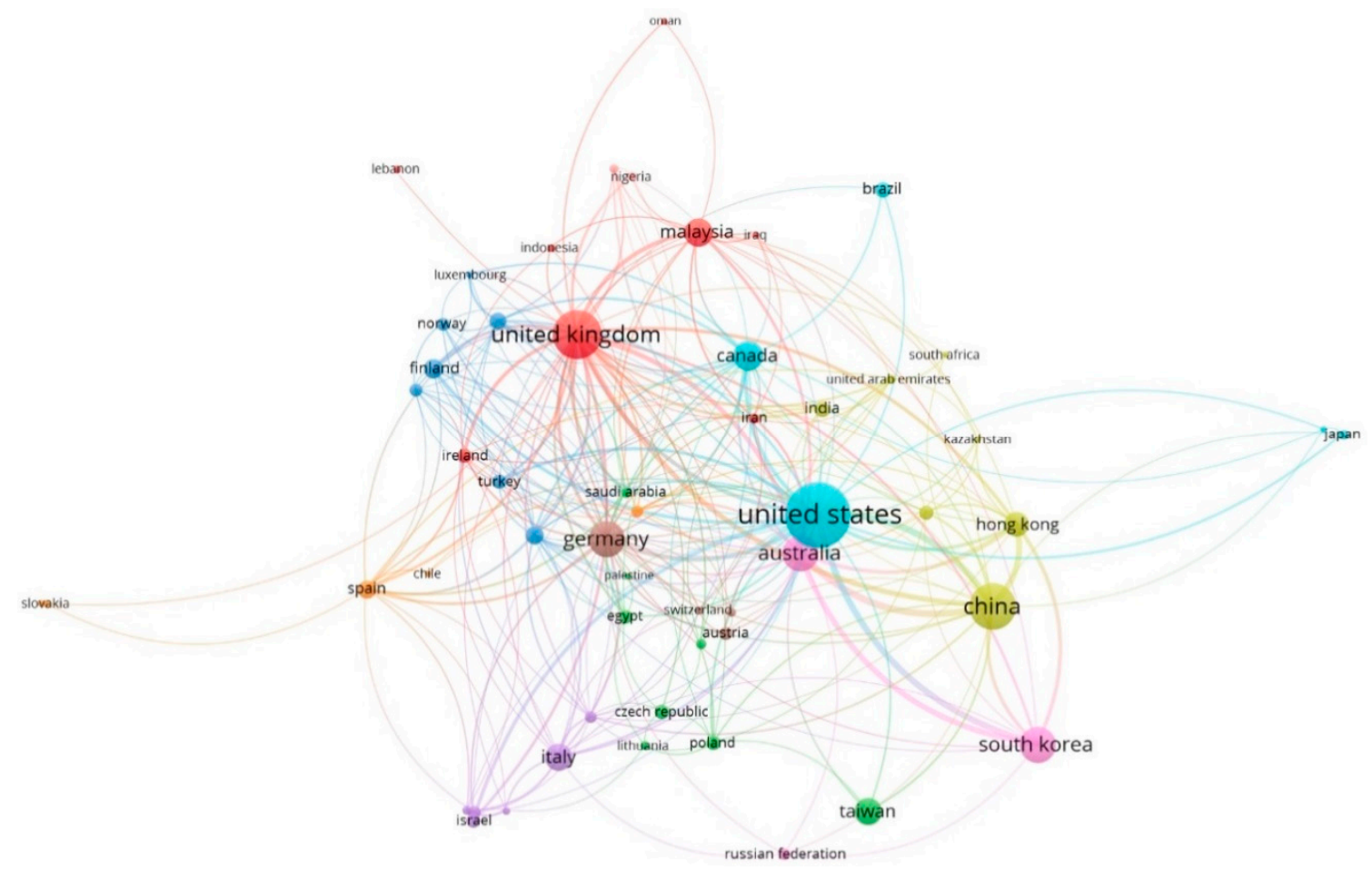

Figure 6. Countries network of BIM publications.

\subsection{Keyword Analysis}

The keywords analysis identifies the common interests of the researchers and their work. In this section we analyze the keywords acquired from the main query as well as their frequency of appearance in every article during the period studied. If the main keywords associated with the theme of the global BIM are analyzed, those of Table 2 are obtained, where the 15 main keywords have been selected. The words of the search itself, such as BIM or Building Information Modeling or Building Information Modelling, have not been taken into account (since it is written in both forms almost equally frequently). It is noted that the general main search keywords are also the first keywords of the particular search in 
universities. However, in the latter case there are, as expected, issues related to teaching: Students, Curricula, Teaching, Education, or Engineering Education.

Table 2. Main keywords related with both queries.

\begin{tabular}{cccc}
\hline BIM & N & BIM in Universities & N \\
\hline Architectural Design & 3075 & Architectural Design & 168 \\
Information Theory & 1295 & Information Theory & 66 \\
Construction Industry & 935 & Construction Industry & 41 \\
Buildings & 671 & Students & 40 \\
Construction & 642 & Buildings & 39 \\
Project Management & 602 & Curricula & 38 \\
Information Management & 458 & Project Management & 37 \\
Structural Design & 458 & Teaching & 37 \\
Life Cycle & 377 & Construction & 35 \\
Construction Projects & 354 & Education & 35 \\
Sustainable Development & 291 & College Buildings & 34 \\
Office Buildings & 279 & Information Management & 30 \\
Design & 255 & Engineering Education & 27 \\
Computer Aided Design & 239 & Surveys & 20 \\
Decision Making & 224 & Life Cycle & 19 \\
\hline
\end{tabular}

The more interesting data are the keywords College Buildings, which show that BIM is starting to also be applied for the construction of university buildings, while global BIM is mainly focused on office buildings. If a visual representation is made with clouds of the keywords, then Figure 7; Figure 8 are obtained. These figures show where a particular study has to be done for automation, sustainable development, or industry foundation classes (IFC).

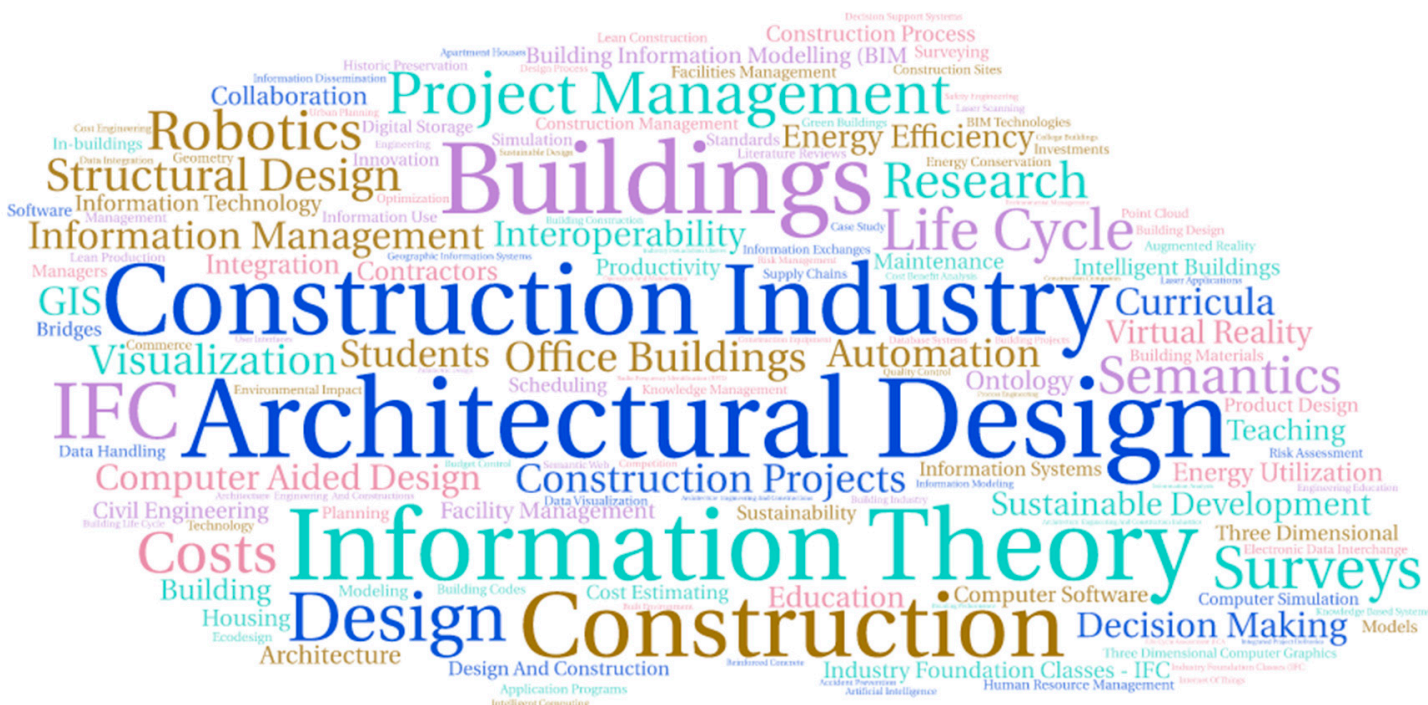

Figure 7. Word cloud of keywords related to BIM (global query). 


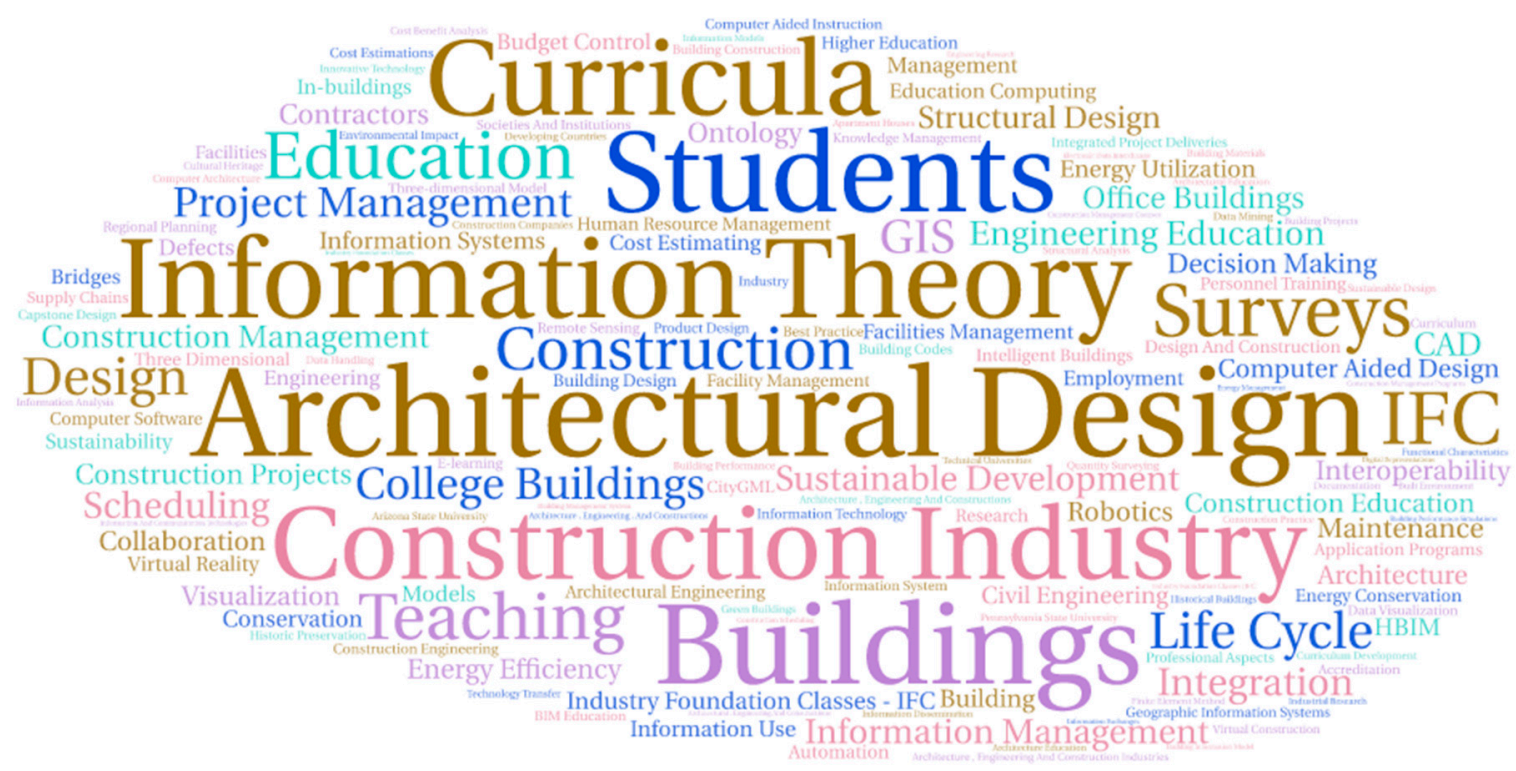

Figure 8. Word cloud of keywords related to BIM in universities.

Figure 9 shows the evolution of the following keywords: automation, sustainable development, and IFC. The three-keyword records were correlated during the greater part of the period studied. In addition, automation and sustainable development had approximately the same level of variance in the same value until 2013, when the gap started to grow wider between them. The automation record continued to increase remarkably until it reached 94 records in 2018. IFC had been scoring a lower score than sustainable development until the year 2018, when IFC obtained 53 records and sustainable development obtained 33 records.

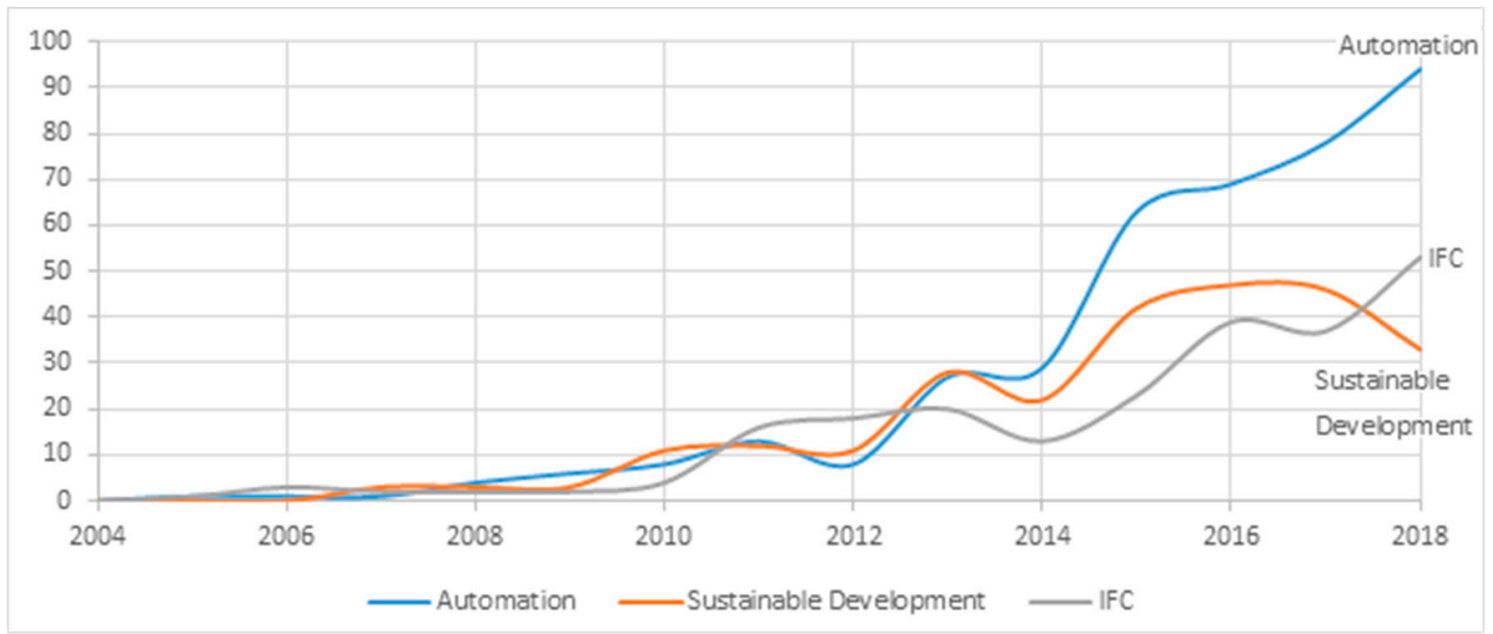

Figure 9. Countries network of BIM publishers and their community detection.

The major topics in Table 3 and Figure 10 constitute the structure of BIM. Management is the first topic that most relevant keywords evolve around, while the technology of BIM plays a crucial role in improving the interaction between different contributors and the ways in which they manage various aspects of the project development and BIM implementation during the building life cycle. 
Table 3. Main keywords used by the communities detected in the topic BIM.

\begin{tabular}{cccc}
\hline Cluster & Color & Main Keywords & Topic \\
\hline 1 & Red & $\begin{array}{c}\text { Construction management -Collaboration-Information } \\
\text { technology-Bim adoption }\end{array}$ & $\begin{array}{c}\text { Construction } \\
\text { management }\end{array}$ \\
\hline 2 & Green & $\begin{array}{c}\text { Interoperability-Facility management-Industry } \\
\text { foundation classes -Internet of Things }\end{array}$ & $\begin{array}{c}\text { Documentation and } \\
\text { Analysis }\end{array}$ \\
\hline 3 & Blue & Architecture-Virtual Reality-Education-GIS & Architecture and Design \\
\hline 5 & Orange & Lean construction-Implementation-Adoption & Construction/Fabrication \\
\hline 5 & Yellow & $\begin{array}{c}\text { Energy efficiency-sustainable design-Leadership in } \\
\text { Energy and Environmental Design-energy } \\
\text { simulation-Building performance }\end{array}$ & $\begin{array}{c}\text { Operation and } \\
\text { maintenance }\end{array}$ \\
\hline
\end{tabular}

Figure 10 illustrates numerous keyword clusters in the form of a neural network with different colors, where the co-occurrence of keywords occurs at least 5 times. Each node is a keyword, and the link thickness between nodes represents the degree of connection. The BIM keywords analysis has identified six communities using a community detection algorithm and Table 2 shows their main clusters by their order of importance. The most significant clusters besides building information model are construction, interoperability, virtual reality, architecture, collaboration and construction management, visualization, and automation. These communities provide a general indication of the fields that are related to BIM, which are diverse and technology oriented.

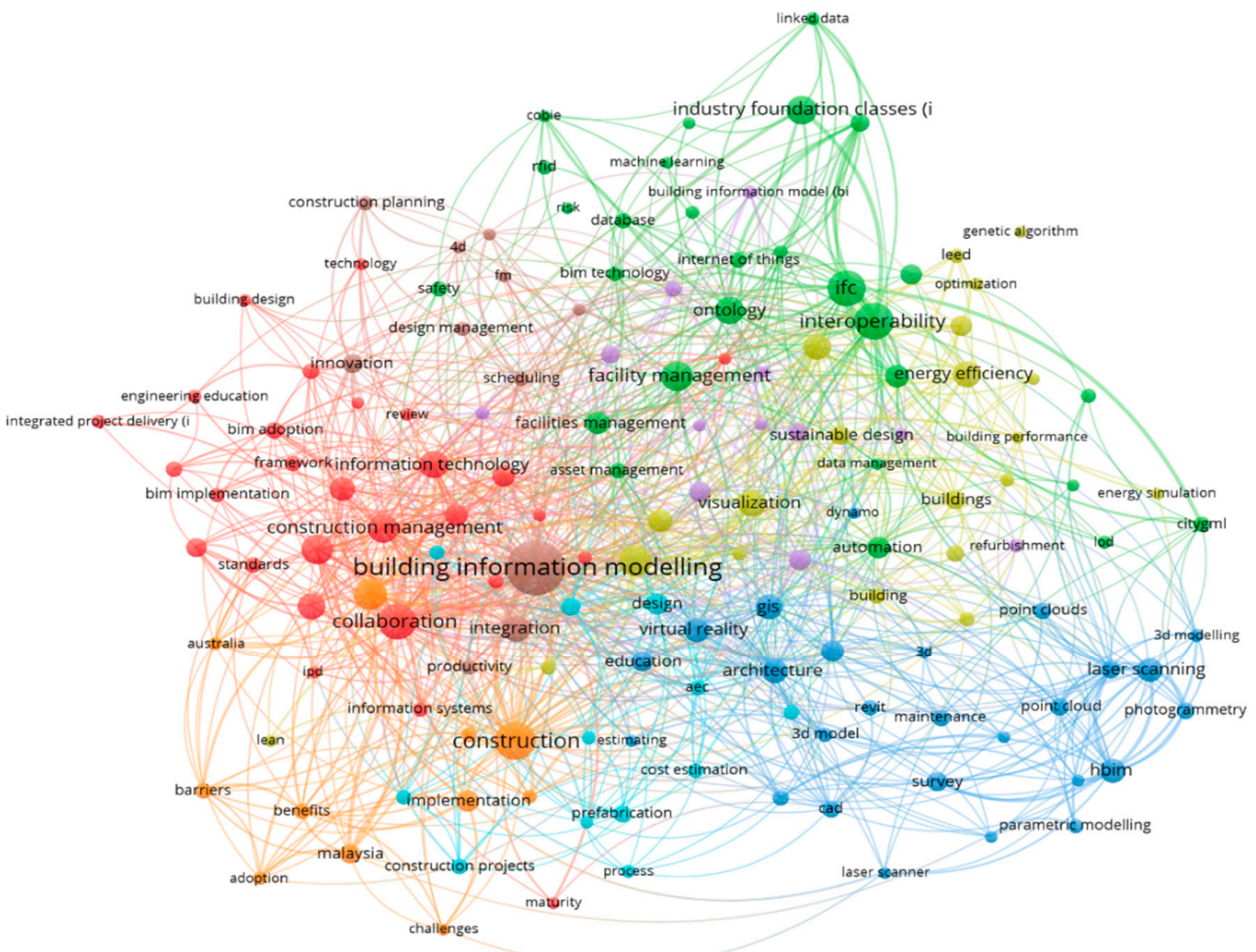

Figure 10. Keywords co-occurrence network related to BIM worldwide. 
Analyzing the first cluster, in red in Figure 11, where only keywords with a minimum of 15 co-occurrences have been highlighted, it can be seen that it is related to construction management, collaboration, information technology, and BIM adoption. This shows that BIM is not only useful for geometric modeling of a building's performance but can also assist in the management of construction projects [56]. Some works highlight the synergy between facility management and BIM as a basis for multidisciplinary collaboration [57]. Within this community or cluster, the information technology that is developing object-oriented Computer Aided Design (CAD) tools compatible with BIM can be found, such as analysis tools, model verifiers, and facility management applications [58]. It should be remembered that the main difference between BIM technology and conventional 3D CAD is that the latter describes a building through independent 3D views, such as plans, while BIM uses all the information related to the building, including its physical and functional characteristics and information about the project life cycle, in a series of "smart objects" [59].

The second cluster, in green in Figure 12, where only keywords with a minimum of 15 co-occurrences have been highlighted, is shown to be associated with interoperability, facility management, industry foundation classes, and IoT. BIM is an expansive area of knowledge inside the architecture, engineering and construction industry [60]. An example of this is building automation, e.g., for on-site assembly services in prefabricated buildings with IoT, where the IoT-enabled platform can provide various decision support tools and services to different stakeholders [61]. As an example of industry foundation classes, it is possible to find works where various standards have been published, leading up to the 10-year development of industry foundation classes [62].

The cluster related to architecture, cluster 3 with the color blue in Figure 13, where only keywords with a minimum of 15 co-occurrences have been highlighted, has architecture; virtual reality, education, and GIS as the main related keywords. BIM offers the potential to achieve a lower project cost, increase productivity and quality, and reduce project turnaround time [58]. There are several great examples in the literature of the integration of architecture and GIS showing benefits such as reusability and extensibility [63]. Virtual reality is relevant because it allows us to make a 3D reconstruction of architecture appearance [64]. Both areas are very important in teaching, e.g., for the teaching of architecture through augmented reality $[65,66]$.

The orange cluster four in Figure 14, is mainly related to the keyword's lean construction, implementation, and adoption benefits, cost/benefit analysis, awareness raising, and education and training, all of which are important activities to address the challenges of BIM usage. From the analysis of numerous works related to BIM, it was inferred that the benefit of BIM most frequently relates to cost reduction and control throughout the project life cycle, but significant time savings were also reported. The costs of BIM focused primarily on the use of BIM software [67]. Of course, the benefits are proportional to the form of implementation of the BIM [68].

The last cluster, in yellow in Figure 15, where only keywords with a minimum of 15 co-occurrences have been highlighted, focuses on the keywords: Energy efficiency, sustainable design, leadership in energy, environmental Design, energy simulation, and building performance. For a sustainable building, the use of its energy always involves customers and designers [69]. This includes important aspects of environmental design, e.g., to determine what the forecast $\mathrm{CO} 2$ emissions are from the building and whether it will meet the performance criteria [70]. It should be noted that retrofitting of existing buildings offers significant opportunities for reducing global energy consumption and greenhouse gas emissions [71,72]. Therefore, a model based on BIM that can enhance the post-occupancy assessment processes and meet the industry standards for sustainable buildings would be useful. 


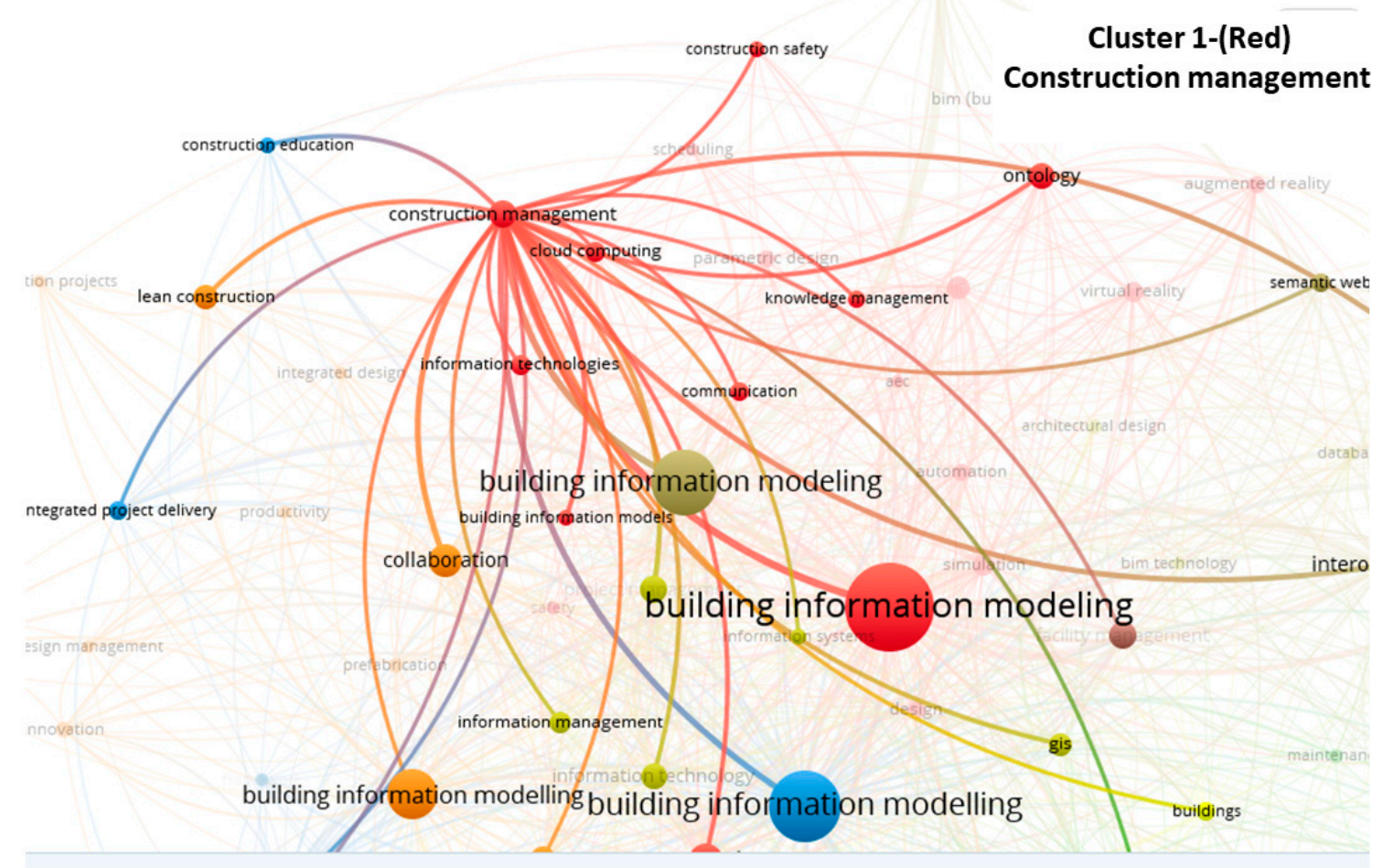

Figure 11. Keywords co-occurrence for cluster 1 (Construction management).

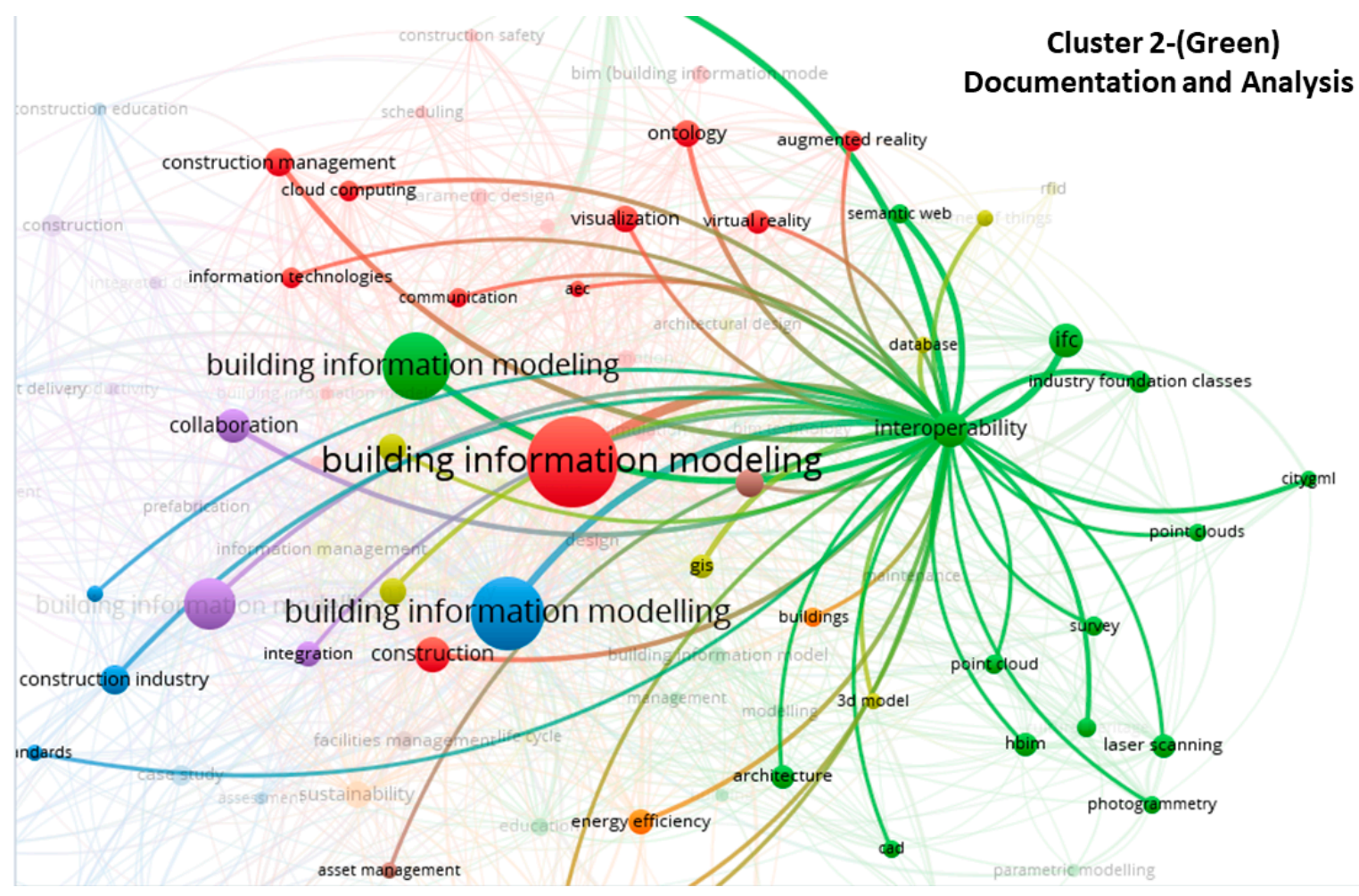

Figure 12. Keywords co-occurrence for cluster 2 (Documentation and Analysis). 


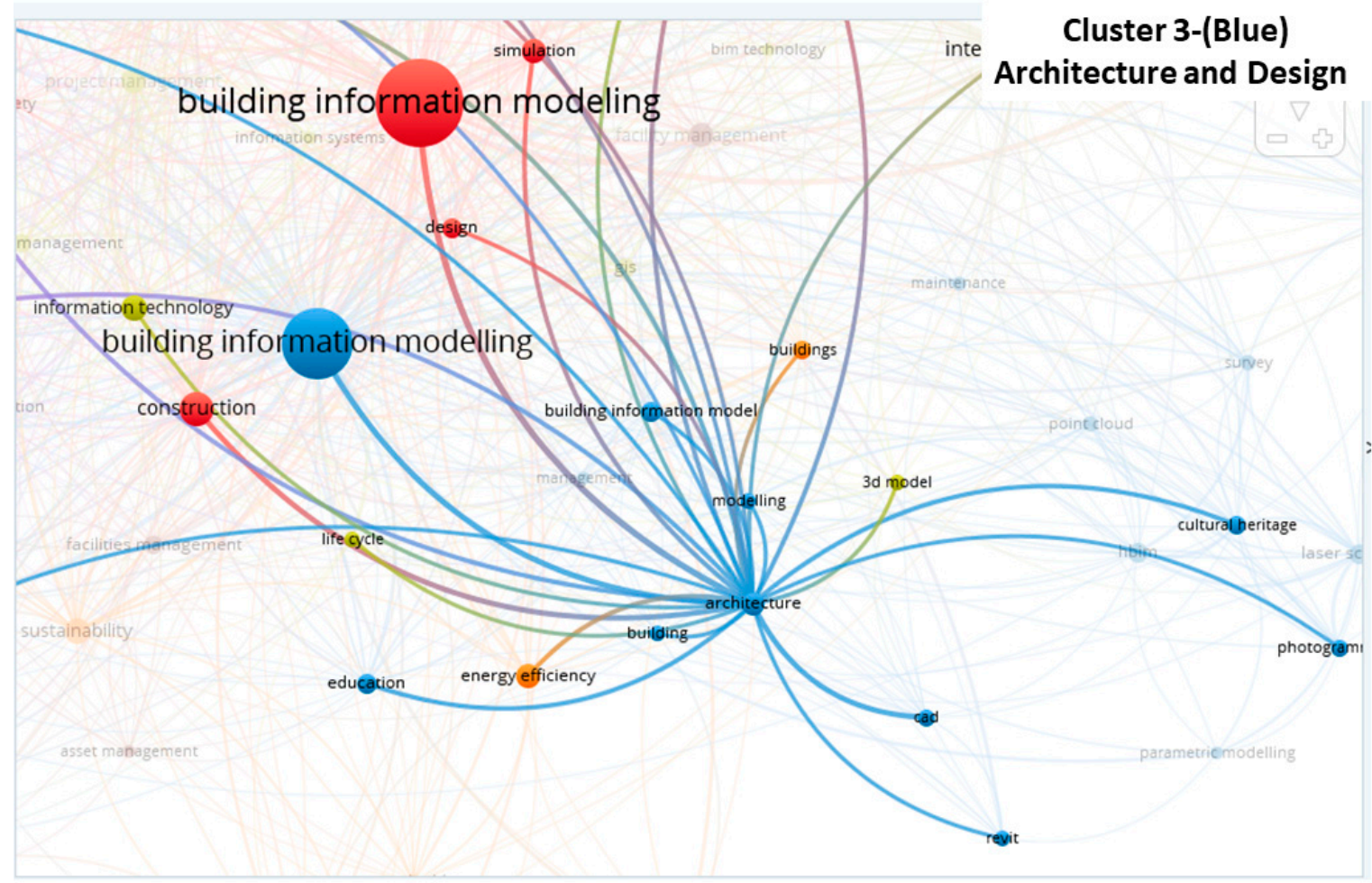

Figure 13. Keywords co-occurrence for cluster 3 (Architecture and Design).

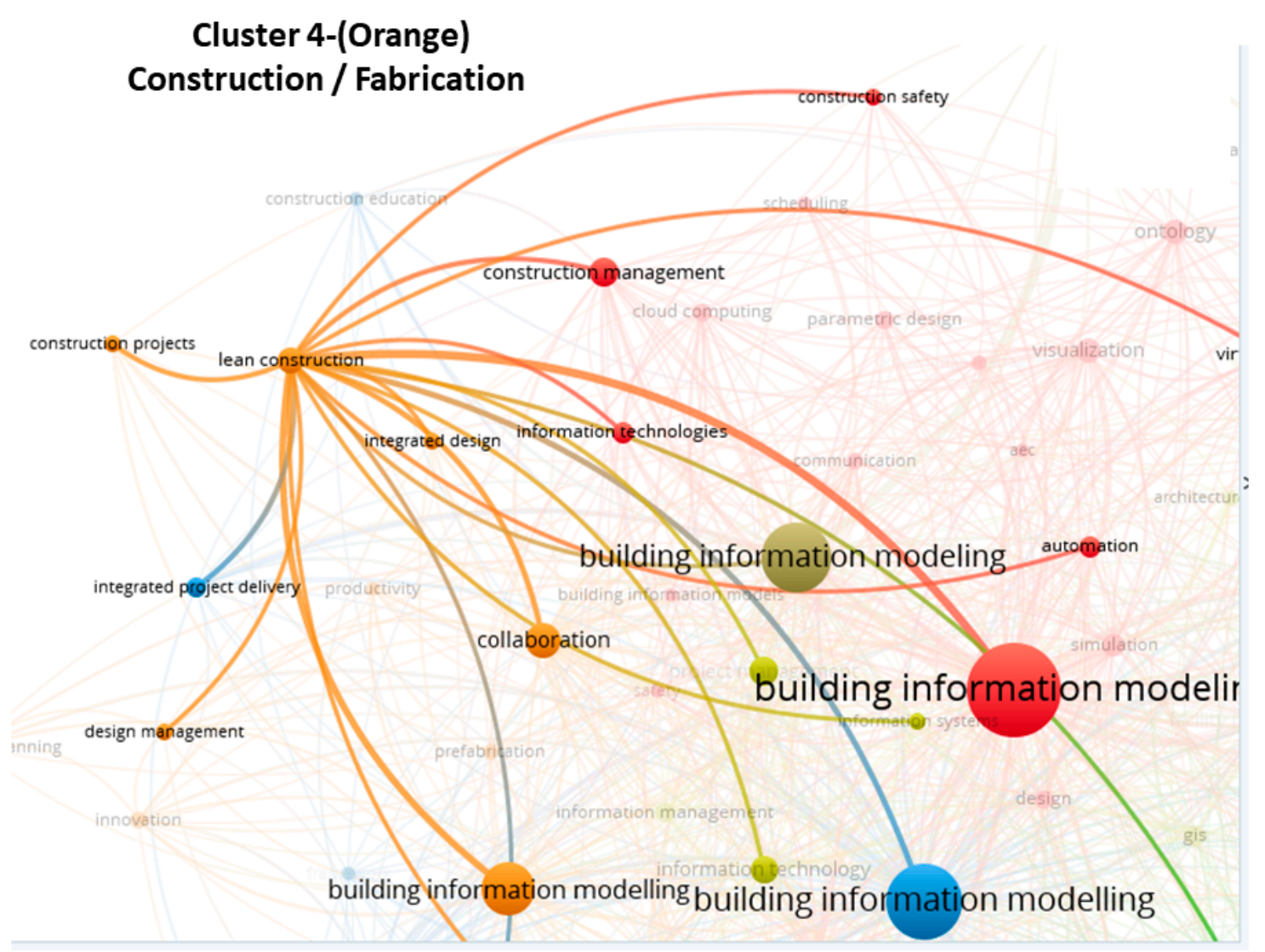

Figure 14. Keywords co-occurrence for cluster 4 (Construction / Fabrication). 


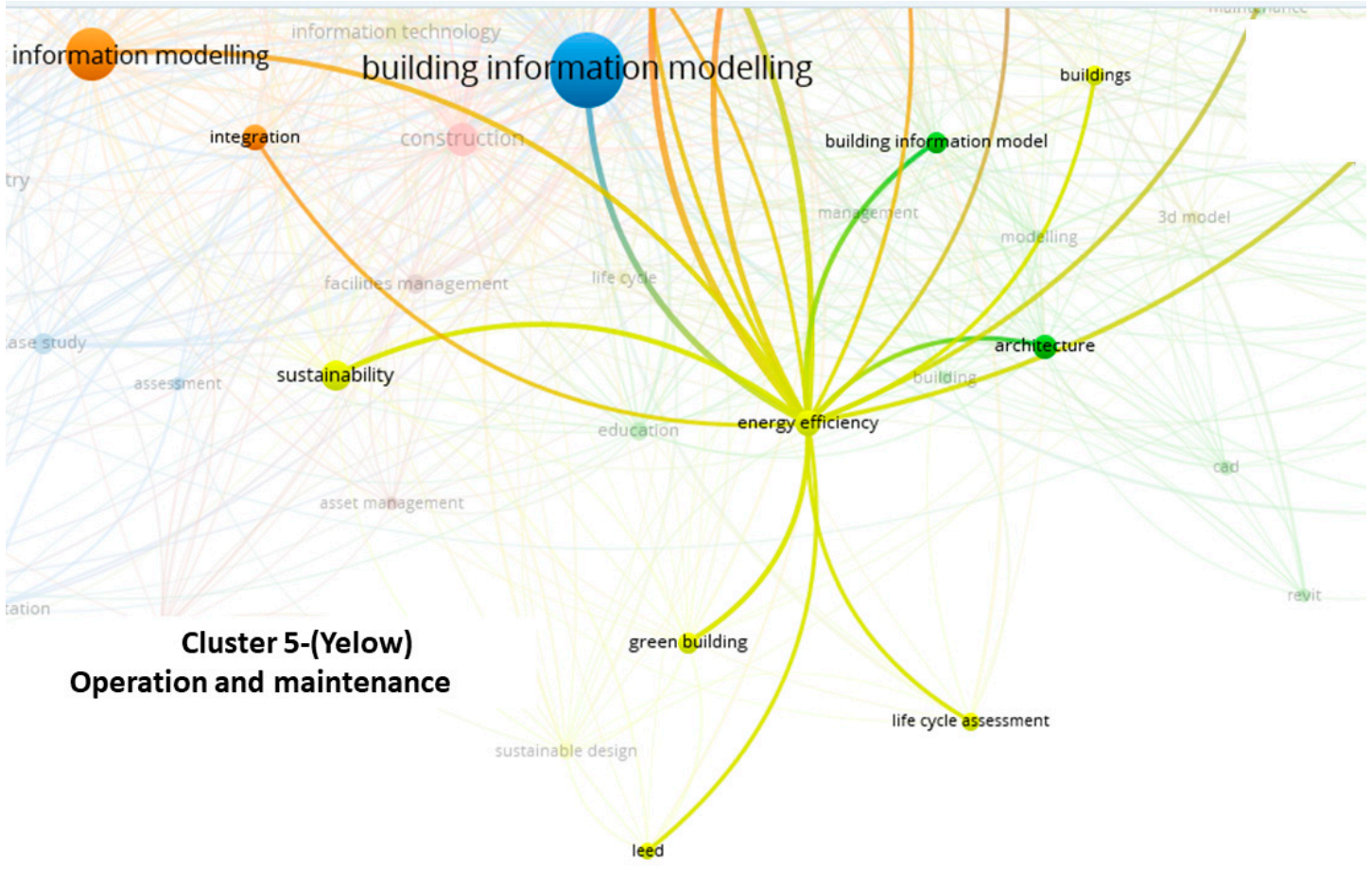

Figure 15. Keywords co-occurrence for cluster 5 (Operation and maintenance).

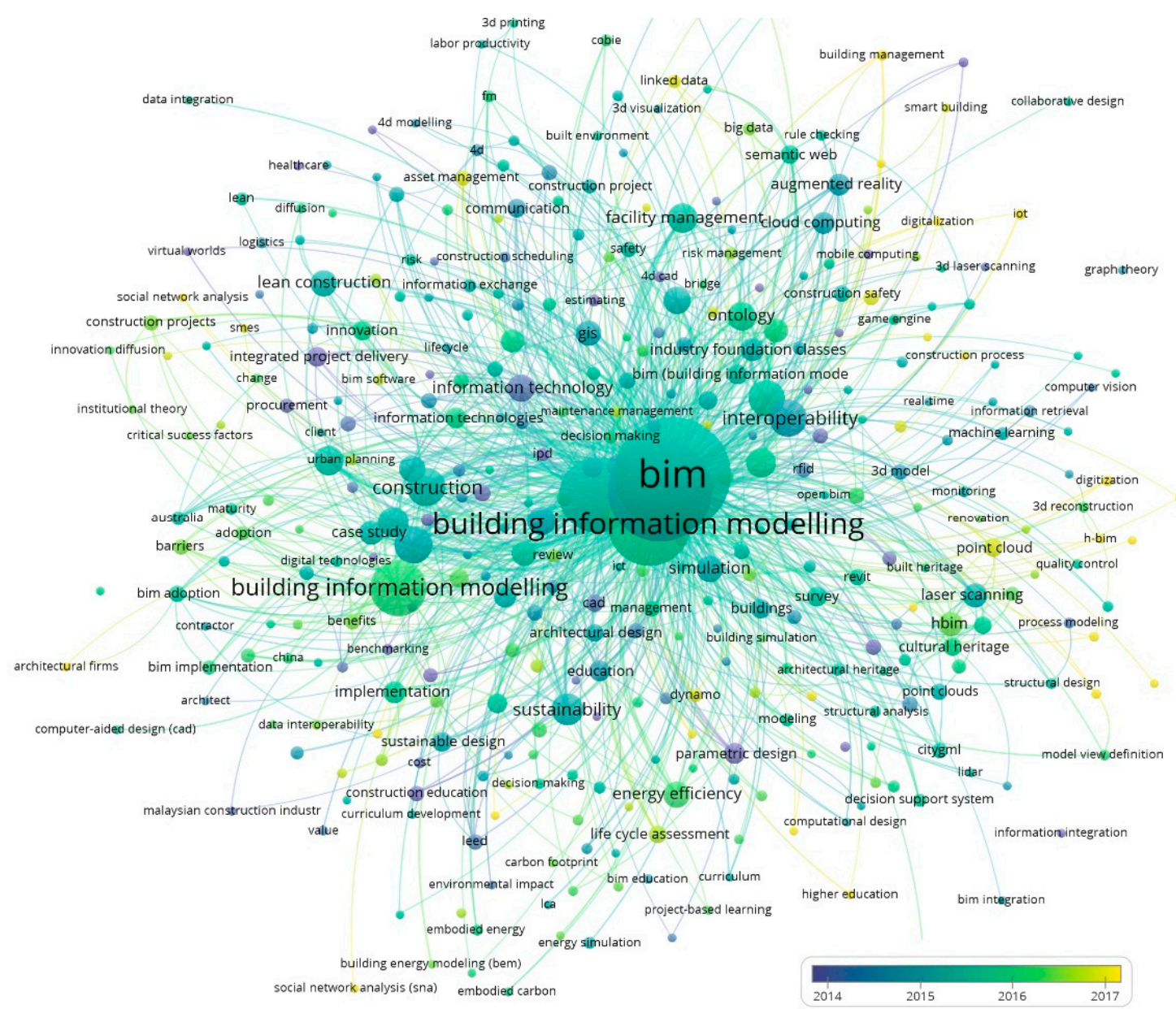

Figure 16. Evolution BIM research (2014-2017). 
The network analysis illustrates the evolution of BIM within the period from 2014 to 2017 (Figure 16). It shows that all the major clusters spread from the central communities that represent BIM in different designations, while this analysis also reveals the structure of the current network and the composition of the future trends.

Of the whole studied period of BIM research, i.e., from 2003 to 2018, the period with the highest rate of evolution in BIM research found is from 2014 to 2017. In those years, the keywords were (indicated by purple in the year 2014): cad, parametric design, information technology, built heritage or integrated project delivery. In the years 2015-2016 (indicated in green) the main keywords were: lean construction, GIS, facility management, energy efficiency, or sustainability. The end of the evolution period (yellow, the year 2017) is shown by frequent keywords used: social network analysis, IoT, safety, SMES as the acronym for Small and Medium-sized Enterprises, and higher education. This evolution shows how information concepts and technologies have been incorporated into the research of the BIM as the IoT, obtaining importance in the curricula of students of higher education in careers such as engineering and architecture as a key factor for BIM implementation [73-75].

\section{Discussion}

Countries like China, the UK, Canada, South Korea, Germany, the USA, Australia and Italy are among the top publishers of both BIM global and BIM in universities. The geographic location plays a major role in the composition of most of the clusters. The UK's cluster is larger than more than six countries outside of the European continent combined. In addition, China is the leader in research about BIM within the Asian continent. The collaborating work of authors shapes the bibliometric map of BIM through numerous parameters, while citation network analysis of the cited references indicates a wide range of subjects in this field of research such as computer science, engineering, business, management and accounting. These different subjects show the diversity of this research area. The keywords analysis provided a list of diverse words related to themes like architectural design, construction management, interoperability, lean construction, virtual reality, visualization, robotics and sustainability development. The extensive amount of data that is generated to improve the facilities management requires multidisciplinary applications of BIM. Therefore, the use of advanced technology is emerging in order to be able to respond properly to market challenges. BIM applications are moving towards IoT, safety, digitalization, smart building, social network analysis, and point cloud. Thus, automation will play a significant role either in providing a highly accurate 3D model for the existing buildings, or in providing a system that measures, collects, and analyzes data of the key performance metrics based on the IoT concept. Furthermore, a digitally empowered framework will enable the decentralization of facilities management for single or multiple buildings [20,21], and could provide a finished product to end-users for cognitive building operation. In term of safety, professionals and researchers are working to develop an approach to integrate the risk factor in building an information model. The tool will be able to detect and quantify automatically any potential risk within the construction site and the life cycle of the project $[17,19,26]$. Several studies have applied social network analysis (SNA) to investigate major risks related to the act of building and to identify the network structure of all the contributor relationships [26]. Other research suggests using risk factors integration from an online application called the Safety in Design Risk Evaluator, which measures risks at the item-level in multistory buildings with a $4 \mathrm{D}$ building information model and a construction timetable [31]. Therefore, BIM trends as many other concepts are mainly heading towards the adoption of digital technologies, big data, IoT, smart models, and machine learning. The expertise areas extracted from the co-occurrence network include interoperability, IFC, lean construction, BIM implementation, energy efficiency and BIM education. Most of these fields are technology based, which has led to a fast-growing knowledge of BIM and its sub-areas that we can see in the evolution pattern. Therefore, BIM education should be constantly upgraded to deliver a valuable knowledge of this dynamic platform. 
BIM should be understood as cycle where are all the phases related to the building industry. These phases are: programming, conceptual design, analysis, documentation, fabrication, construction, construction logistics or management, operation and maintenance, demolition, and renovation. The clusters obtained in the previous section reflect almost all of these phases of the BIM, but the cluster of demolition and renovation are missing. This gap in BIM research is already pointed out by some recent works [76]. This shows that these two fields of research within the BIM; although they are currently not fully developed.

\section{Conclusions}

This bibliometric approach can meaningfully contribute to the ongoing manual review of BIM. Conference papers are the main source of scientific publications, followed by scientific article and reviews. Experts and researchers mostly contribute to expanding BIM literature through these channels, and the rest are published through book chapters, conference reviews and article publications. The scientific contribution in this study refers to 4307 articles associated with BIM, where only $6.4 \%$ of these articles related are to BIM in universities and $46 \%$ is published in just three countries, which are the USA, UK, and China. The bibliographic records provide users with necessary data about the affiliation of different articles. Furthermore, four out of sixteen universities are present for both of the research topics BIM and BIM in universities. Georgia Institute of Technology and Pennsylvania State University are the leaders in this emerging area of research. It is also observed that the countries that made the usage of BIM mandatory in the regulation of construction are the ones which have the most interest in researching and developing this concept. The five clusters obtained in BIM research are those of the cycle in which all phases related to the construction industry are found: construction management, documentation and analysis, architecture and design, construction / fabrication, and operation and maintenance (related to energy or sustainability). However, the clusters of the last phases such as demolition and renovation are not present, which indicates a field that still needs to be developed and researched. With regard to the evolution of research, it has been observed how information technologies have been integrated with IoT. Finally, a key factor in the implementation of the BIM is its inclusion in the curriculum of technical careers related to construction such as civil engineering or architecture. Therefore, in order to remain up to date and meaningful, education in construction needs to take advantage of the opportunities and overcome the challenges presented by BIM. This bibliometric analysis provides a general overview of the subject in order to concentrate on the strategies that are still relevant and to open up promising new lines of research. This work opens new perspectives for the use of the BIM in universities, which has been found to be less extensively covered than BIM at a global level.

Author Contributions: M.C. dealt with literature review and article writing. E.S.-M. and N.N. analyzed the data and formatting. F.M.-A. Research idea, article writing. They share the structure and aims of the manuscript, paper drafting, editing and review. All authors have read and approved the final manuscript.

Funding: This research received no external funding.

Conflicts of Interest: The authors declare no conflict of interest.

\section{References}

1. Eastman, C.; Teicholz, P.; Sacks, R.; Liston, K. BIM Handbook: A Guide to Building Information Modeling for Owners, Managers, Designers, Engineers and Contractors; John Wiley \& Sons: Hoboken, NJ, USA, 2011.

2. Hergunsel, M.F. Benefits of Building Information Modeling for Construction Managers and BIM Based Scheduling. Master's Thesis, Worcester Polytechnic Institute, Worcester, MA, USA, 2011.

3. Rynne, C. Industrial Ireland 1750-1930: An Archaeology; Collins Press: New York, NY, USA, 2006.

4. Sturdevant, J.R.; Bayne, S.C.; Heymann, H.O. Margin gap size of ceramic inlays using second-Generation CAD/CAM equipment. J. Esthet. Restor. Dent. 1999, 11, 206-214. [CrossRef] 
5. Goodacre, C.J.; Garbacea, A.; Naylor, W.P.; Daher, T.; Marchack, C.B.; Lowry, J. CAD/CAM fabricated complete dentures: Concepts and clinical methods of obtaining required morphological data. J. Prosthet. Dent. 2012, 107, 34-46. [CrossRef]

6. Engelbart, C. Augmenting Human Intellect: A Conceptual Framework; Doug Engelbart Institute: Menlo Park, CA, USA, 1962.

7. Eastman, C. The use of computers instead of drawings in building design. AIA J. 1975, 63, 46-50.

8. Eastman, C.; Henrion, M. Glide: A Language for Design Information Systems. In ACM SIGGRAPH Computer Graphics; ACM: New York, NY, USA, 1977.

9. Aish, R. Three-dimensional input and visualization. In Computer-Aided Architectural Design Futures; Butterworth-Heinemann: Oxford, UK, 1986; pp. 68-84.

10. Van Nederveen, G.A.; Tolman, F.P. Modeling multiple views on buildings. Autom. Constr. 1992, 1, $215-224$. [CrossRef]

11. Vysotskiy, A.; Makarov, S.; Zolotova, J.; Tuchkevich, E. Features of BIM implementation using autodesk software. Procedia Eng. 2015, 117, 1143-1152. [CrossRef]

12. Ulmanis, J. CASE 6: Graphisoft: The Architecture of International Growth; Entrepreneurial Icebreakers; Palgrave Macmillan: London, UK, 2015; pp. 193-209.

13. Mueller, V.; Smith, M. Generative Components and Smartgeometry: Situated Software Development. Inside Smartgeometry Expand. Archit. Possibilities Comput. Des. 2013, 2013, 142-153.

14. Watson, A. Digital buildings-Challenges and opportunities. Adv. Eng. Inform. 2011, 25, 573-581. [CrossRef]

15. Poole, M.; Shvartzberg, M. (Eds.) The Politics of Parametricism: Digital Technologies in Architecture; Bloomsbury Publishing: London, UK, 2015.

16. Wu, P.; Wang, J.; Wang, X. A critical review of the use of 3-D printing in the construction industry. Autom. Constr. 2016, 68, 21-31. [CrossRef]

17. Macher, H.; Landes, T.; Grussenmeyer, P. From point clouds to building information models: 3D semi-automatic reconstruction of indoors of existing buildings. Appl. Sci. 2017, 7, 1030. [CrossRef]

18. Ochmann, S.; Vock, R.; Klein, R. Automatic reconstruction of fully volumetric 3D building models from oriented point clouds. ISPRS J. Photogramm. Remote Sens. 2019, 151, 251-262. [CrossRef]

19. Wang, C.; Cho, Y.K.; Kim, C. Automatic BIM component extraction from point clouds of existing buildings for sustainability applications. Autom. Constr. 2015, 56, 1-13. [CrossRef]

20. Teizer, J.; Wolf, M.; Golovina, O.; Perschewski, M.; Propach, M.; Neges, M.; König, M. Internet of things (IoT) for integrating environmental and localization data in building information modeling (BIM). In Proceedings of the International Symposium on Automation and Robotics in Construction (ISARC), Vilnius Gediminas Technical University, Department of Construction Economics \& Property, Taipei, Taiwan, 28 June-1 July 2017; Volume 34.

21. Pasini, D.; Ventura, S.M.; Rinaldi, S.; Bellagente, P.; Flammini, A.; Ciribini, A.L.C. Exploiting Internet of Things and building information modeling framework for management of cognitive buildings. In Proceedings of the 2016 IEEE International Smart Cities Conference (ISC2), Trento, Italy, 12-15 September 2016; Volumes 1-6.

22. Deng, Y.; Cheng, J.C.P.; Anumba, C. Mapping between BIM and 3D GIS in different levels of detail using schema mediation and instance comparison. Autom. Constr. 2016, 67, 1-21. [CrossRef]

23. Liu, X.; Wang, X.; Wright, G.; Cheng, J.C.P.; Li, X.; Liu, R. A state-of-the-art review on the integration of Building Information Modeling (BIM) and Geographic Information System (GIS). ISPRS Int. J. Geo Inf. 2017, 6, 53. [CrossRef]

24. Irizarry, J.; Karan, E.P.; Jalaei, F. Integrating BIM and GIS to improve the visual monitoring of construction supply chain management. Autom. Constr. 2013, 31, 241-254. [CrossRef]

25. Li, C.Z.; Hong, J.; Xue, F.; Shen, G.Q.; Xu, X.; Mok, M.K. Schedule risks in prefabrication housing production in Hong Kong: A social network analysis. J. Clean. Prod. 2016, 134, 482-494. [CrossRef]

26. Jin, Z.; Gambatese, J.; Liu, D.; Dharmapalan, V. Risk Assessment in 4D Building Information Modeling for Multistory Buildings. In Proceedings of the Joint CIB W099 and TG59 Conference, Coping with the Complexity of Safety, Health, and Wellbeing in Construction, Salvador, Brazil, 1-3 August 2018; pp. 84-92.

27. McGlinn, K.; Wagner, A.; Pauwels, P.; Bonsma, P.; Kelly, P.; O'Sullivan, D. Interlinking geospatial and building geometry with existing and developing standards on the web. Autom. Constr. 2019, 103, 235-250. [CrossRef] 
28. Mishchenko, E.S.; Monastyrev, P.V.; Evdokimtsev, O.V. Improving the Quality of Training in Building Information Modeling. In International Conference on Interactive Collaborative Learning; Springer: Cham, Switzerland, 2018; pp. 453-459.

29. Alwan, Z.; Jones, P.; Holgate, P. Strategic sustainable development in the UK construction industry, through the framework for strategic sustainable development, using Building Information Modeling. J. Clean. Prod. 2017, 140, 349-358. [CrossRef]

30. Bradley, A.; Li, H.; Lark, R.; Dunn, S. BIM for infrastructure: An overall review and constructor perspective. Autom. Constr. 2016, 71, 139-152. [CrossRef]

31. Kassem, M.; Kelly, G.; Dawood, N.; Serginson, M.; Lockley, S. BIM in facilities management applications: A case study of a large university complex. Built Environ. Proj. Asset Manag. 2015, 5, 261-277. [CrossRef]

32. Fan, S.L.; Chong, H.Y.; Liao, P.C.; Lee, C.Y. Latent Provisions for Building Information Modeling (BIM) Contracts: A Social Network Analysis Approach. KSCE J. Civ. Eng. 2019, 23, 1427-1435. [CrossRef]

33. Badrinath, A.C.; Chang, Y.T.; Hsieh, S.H. A review of tertiary BIM education for advanced engineering communication with visualization. Vis. Eng. 2016, 4, 9. [CrossRef]

34. Fan, S.L.; Lee, C.Y.; Chong, H.Y.; Skibniewski, M.J. A critical review of legal issues and solutions associated with building information modeling. Technol. Econ. Dev. Econ. 2018, 24, 2098-2130. [CrossRef]

35. Lee, C.Y.; Chong, H.Y.; Wang, X. Enhancing BIM performance in EPC projects through integrative trust-based functional contracting model. J. Constr. Eng. Manag. 2018, 144, 06018002. [CrossRef]

36. Nawari, N.O. BIM Data Exchange Standard for Hydro-Supported Structures. J. Archit. Eng. 2019, 25, 04019015. [CrossRef]

37. Manzano-Agugliaro, F.; Calero, M.S.; Perea-Moreno, A.J.; De San Antonio Gomez, C. Ensayo de segregación en cimentaciones para la estructura soporte de aerogeneradores off-shore hechas por vertido en caída libre. DYNA 2018, 93, 221-227. [CrossRef]

38. Nawari, N.O.; Ravindran, S. Blockchain and the built environment: Potentials and limitations. J. Build. Eng. 2019, 25, 100832. [CrossRef]

39. Nawari, N.O.; Ravindran, S. Blockchain technology and BIM process: Review and potential applications. J. Inf. Technol. Constr. 2019, 24, 209-238.

40. Salmerón-Manzano, E.; Manzano-Agugliaro, F. The Role of Smart Contracts in Sustainability: Worldwide Research Trends. Sustainability 2019, 11, 3049. [CrossRef]

41. Maskil-Leitan, R.; Reychav, I. BIM's social role in building energy modeling. Clean Technol. Environ. Policy 2019, 21, 307-338. [CrossRef]

42. Gao, H.; Koch, C.; Wu, Y. Building information modeling based building energy modeling: A review. Appl. Energy 2019, 238, 320-343. [CrossRef]

43. Abanda, F.H.; Byers, L. An investigation of the impact of building orientation on energy consumption in a domestic building using emerging BIM (Building Information Modeling). Energy 2016, 97, 517-527. [CrossRef]

44. Zanni, M.A.; Soetanto, R.; Ruikar, K. Towards a BIM-enabled sustainable building design process: Roles, responsibilities, and requirements. Archit. Eng. Des. Manag. 2017, 13, 101-129. [CrossRef]

45. Bouchlaghem, D.; Shang, H.; Anumba, C.J.; Cen, M.; Miles, J.; Taylor, M. ICT-enabled collaborative working environment for concurrent conceptual design. Archit. Eng. Des. Manag. 2005, 1, 261-280. [CrossRef]

46. Chong, H.Y.; Lee, C.Y.; Wang, X. A mixed review of the adoption of Building Information Modeling (BIM) for sustainability. J. Clean. Prod. 2017, 142, 4114-4126. [CrossRef]

47. Zanni, M.A.; Soetanto, R.; Ruikar, K. Defining the sustainable building design process: Methods for BIM execution planning in the UK. Int. J. Energy Sector Manag. 2014, 8, 562-587. [CrossRef]

48. Crawley, D.B.; Hand, J.W.; Kummert, M.; Griffith, B.T. Contrasting the capabilities of building energy performance simulation programs. Build. Environ. 2008, 43, 661-673. [CrossRef]

49. Crawley, E.; Malmqvist, J.; Ostlund, S.; Brodeur, D.; Edstrom, K. Rethinking engineering education. CDIO Approach 2007, 302, 60-62.

50. Li, X.; Wu, P.; Shen, G.Q.; Wang, X.; Teng, Y. Mapping the knowledge domains of Building Information Modeling (BIM): A bibliometric approach. Autom. Constr. 2017, 84, 195-206. [CrossRef] 
51. Zhao, X. A scientometric review of global BIM research: Analysis and visualization. Autom. Constr. 2017, 80, 37-47. [CrossRef]

52. Olawumi, T.O.; Chan, D.W.; Wong, J.K. Evolution in the intellectual structure of BIM research: A bibliometric analysis. J. Civ. Eng. Manag. 2017, 23, 1060-1081. [CrossRef]

53. Oraee, M.; Hosseini, M.R.; Papadonikolaki, E.; Palliyaguru, R.; Arashpour, M. Collaboration in BIM-based construction networks: A bibliometric-qualitative literature review. Int. J. Proj. Manag. 2017, 35, 1288-1301. [CrossRef]

54. Wong, J.K.W.; Zhou, J. Enhancing environmental sustainability over building life cycles through green BIM: A review. Autom. Constr. 2015, 57, 156-165. [CrossRef]

55. Aghaei Chadegani, A.; Salehi, H.; Yunus, M.M.; Farhadi, H.; Fooladi, M.; Farhadi, M.; Ale Ebrahim, N. A comparison between two main academic literature collections: Web of science and scopus databases. Asian Soc. Sci. 2013, 9, 18-26. [CrossRef]

56. Bryde, D.; Broquetas, M.; Volm, J.M. The project benefits of building information modeling (BIM). Int. J. Proj. Manag. 2013, 31, 971-980. [CrossRef]

57. Becerik-Gerber, B.; Jazizadeh, F.; Li, N.; Calis, G. Application areas and data requirements for BIM-enabled facilities management. J. Constr. Eng. Manag. 2011, 138, 431-442. [CrossRef]

58. Singh, V.; Gu, N.; Wang, X. A theoretical framework of a BIM-based multi-disciplinary collaboration platform. Autom. Constr. 2011, 20, 134-144. [CrossRef]

59. Azhar, S.; Khalfan, M.; Maqsood, T. Building information modeling (BIM): Now and beyond. Constr. Econ. Build. 2012, 12, 15-28. [CrossRef]

60. Succar, B. Building information modeling framework: A research and delivery foundation for industry stakeholders. Autom. Constr. 2009, 18, 357-375. [CrossRef]

61. Li, C.Z.; Xue, F.; Li, X.; Hong, J.; Shen, G.Q. An Internet of Things-enabled BIM platform for on-site assembly services in prefabricated construction. Autom. Constr. 2018, 89, 146-161. [CrossRef]

62. Howard, R.; Björk, B.C. Building information modeling-Experts' views on standardisation and industry deployment. Adv. Eng. Inform. 2008, 22, 271-280. [CrossRef]

63. Azhar, S. Building information modeling (BIM): Trends, benefits, risks, and challenges for the AEC industry. Leadersh. Manag. Eng. 2011, 11, 241-252. [CrossRef]

64. Kang, T.W.; Hong, C.H. A study on software architecture for effective BIM/GIS-based facility management data integration. Autom. Constr. 2015, 54, 25-38. [CrossRef]

65. Ning, X.; Wang, Y. 3D reconstruction of architecture appearance: A survey. Comput. Inf. Syst. 2013, 9, 3837-3848.

66. Kim, J.L. Use of BIM for effective visualization teaching approach in construction education. J. Prof. Issues Eng. Educ. Pract. 2011, 138, 214-223. [CrossRef]

67. Castro-Garcia, M.; Perez-Romero, A.M.; León-Bonillo, M.J.; Manzano-Agugliaro, F. Developing Topographic Surveying Software to Train Civil Engineers. J. Prof. Issues Eng. Educ. Pract. 2016, 143, 04016013. [CrossRef]

68. Volk, R.; Stengel, J.; Schultmann, F. Building Information Modeling (BIM) for existing buildings-Literature review and future needs. Autom. Constr. 2014, 38, 109-127. [CrossRef]

69. Migilinskas, D.; Popov, V.; Juocevicius, V.; Ustinovichius, L. The benefits, obstacles and problems of practical BIM implementation. Procedia Eng. 2013, 57, 767-774. [CrossRef]

70. Motawa, I.; Carter, K. Sustainable BIM-based evaluation of buildings. Procedia Soc. Behav. Sci. 2013, 74, 419-428. [CrossRef]

71. Habibi, S. The promise of BIM for improving building performance. Energy Build. 2017, 153, 525-548. [CrossRef]

72. AlFaris, F.; Juaidi, A.; Manzano-Agugliaro, F. Energy retrofit strategies for housing sector in the arid climate. Energy Build. 2016, 131, 158-171. [CrossRef]

73. Wong, K.D.; Fan, Q. Building information modeling (BIM) for sustainable building design. Facilities 2013, 31, 138-157. [CrossRef]

74. Ku, K.; Taiebat, M. BIM experiences and expectations: The constructors' perspective. Int. J. Constr. Educ. Res. 2011, 7, 175-197. [CrossRef] 
75. Fridrich, J.; Kubečka, K. BIM-the process of modern civil engineering in higher education. Procedia Soc. Behav. Sci. 2014, 141, 763-767. [CrossRef]

76. Cheng, J.C.; Ma, L.Y. A BIM-based system for demolition and renovation waste estimation and planning. Waste Manag. 2013, 33, 1539-1551. [CrossRef]

(c) (

(C) 2019 by the authors. Licensee MDPI, Basel, Switzerland. This article is an open access article distributed under the terms and conditions of the Creative Commons Attribution (CC BY) license (http://creativecommons.org/licenses/by/4.0/). 